\title{
Cimprer \\ [23] \\ Geo-environmental assessment in semiarid region of Pulivendula tehsil, Kadapa district, Andhra Pradesh, India
}

B. P. Bhaskar*

ICAR-National Bureau of Soil Survey and Land Use planning, Regional Centre, Hebbal, Bangalore 560024, India

\begin{abstract}
We aim to integrate geo-environmental datasets in drought afflicted Pulivendula tehsil, Kadapa district for preserving agro-ecosystems with erratic seasonal rains and rapid degradation of natural resource base. An agroecosystem model was devised based on three key inputs which were characterized with agroclimatic data, geopedological data from semi-detailed survey, and a delineation of potential areas for groundnut and banana under drip irrigation. Results of 21 years of rainfall analysis indicate that the region receives $650 \mathrm{~mm}$ of rainfall, providing a productivity of $660 \mathrm{~kg} / \mathrm{ha}$ for groundnut and less than $300 \mathrm{~kg} / \mathrm{ha}$ for red gram, with measurable decreases in area. We derived four clusters and estimated that 35 percent of the area is at high to extremely high risk of soil erosion with poor soil quality (mean of $22.83 \%$ ) and significant differences between the groups. Nearly $35 \mathrm{~K}$ hectares are suitable for banana under drip irrigation and fifty-six thousand hectares are suitable for groundnut cultivation with limitations on rooting depth, topography, coarse fragments, alkalinity, and soil organic matter. Using time series data on crop acreage, productivity, and rainfall in conjunction with geo-environmental data sets under GIS in order to identify ecological health indicators.
\end{abstract}

Keywords

Agricultural landscapes, Cuddapah basin, Drought prone, Land Resource

B] B. P. Bhaskar, Email: bhaskar_phaneendra@yahoo.co.in ( ${ }^{*}$ Corresponding author)

(C) 2021 | Agro Environ Media I Agriculture and Environmental Science Academy, Haridwar, India 


\section{Introduction}

There are 40 percent of land areas at global scale in the arid and semiarid regions, whose environmental problems include the loss of ground water and bio diversity and affecting livelihood of rural communities (Chuvieco et al., 2014; Beroya-Eitner, 2016, Peng et al., 2019). In the twentieth century, we observed rising temperatures and significant changes in climate and environment. We also witnessed ecosystem changes, such as loss of biodiversity, frequent occurrences of extreme weather events, and increasing desertification in semiarid regions (Farley and Voinov, 2016; Heltberg et al., 2009). Analysis of the regional agroecosystems for the conservation of natural resources and to predict the impact of unexpected weather changes under different land use scenarios were reported (Foley et al., 2005; Sun et al., 2018; Wu et al., 2018). The systematic research methodologies were applied in order to understand the natural relationship of landuse change and agro ecosystems in semiarid regions (Arowolo et al., 2018; Mouchet et al., 2017). Most of the studies were made and interpreted landuse change in terms of economic value (Zhou et al., 2018) but Allan et al. (2015) evaluated the biodiversity, functional traits in 14 ecosystems in 150 plots of grasslands under the different landuse intensities. Now the current research trends showed that ecosystem services are linked with land use with natural (Kong et al., 2018) and humanistic features of landscape (Said and Spray, 2018). The linking biophysical methods with ecosystem did not provide enough information for decision makers to incorporate into the appropriate policy decisions (Gong et al., 2017; Zhou et al., 2018). During recent decades, various agro ecological frameworks have been proposed, such as the vulnerability scoping diagram (Polsky et al., 2007), the environmental sensitivity index (Amiri

et al., 2014; Kang et al., 2018), and the pressure-state-response assessment framework (Zhang et al., 2017). In addition to these frameworks, and sensitivity index approaches, the statistical methods such as the principal component analysis (Li et al., 2006), the analytic hierarchy process (AHP) method (Topuz and van Gestel, 2016), the fuzzy comprehensive evaluation method (Adriaenssens et al., 2004) and the entropy methods were used (Amiri et al., 2014; Hou et al., 2015).

The rain fed agriculture in India is in 66\% of total cropped area (Planning Commission, 2012) and occupy second largest producer of rice and wheat under rain fed (FAO, 2018). It was reported that there are drastic climatic changes, perceptibly rise in surface temperature of about $0.4^{\circ} \mathrm{C}$, and decreasing monsoon rainfall of 6-8\% over north eastern India, Gujarat, and Kerala (Government of India, 2008). Climate change of arid and semiarid regions in future will serve as a mark of food starvation risk affecting negatively on food security and rural livelihoods (Krishnamurthy et al., 2012). Indicator methods were used to quantify vulnerability to climate change (Chaliha et al., 2012; Piya et al., 2012) but limited studies focused on vulnerability of small farm holders among rain fed farmer's (Harvey et al., 2014; Gopinath and Bhatt, 2012; Mongi et al., 2010). Several studies related to agricultural drought in India were reported for kharif season (June-September) (Nataraja and Ram Mohan, 2010; Murthy et al., 2011). The agricultural droughts were quantified using both meteorological and satellite-derived indices, such as normalized difference vegetation index (NDVI Dev), vegetation 
condition index (VCI) and standardized precipitation index (SPI) (Dutta et al., 2015; Bhavani et al., 2017). In India, the vulnerability of agro ecological systems of 597 districts were carried out for assessing climatic variability, ecological and demographic sensitivity and socio-economic capacity. The results showed that Western plains, Northern plains, and Central highlands of the arid and semi-arid agroecological zones represent vulnerable regions of the country (1950-2000). The futuristic scenario (2050), clearly shows that Deccan plateau and Central (Malwa) highlands, lying in the arid and semi-arid zones are extremely vulnerable (Shukla et al., 2017). The climatic vulnerability studies for rain fed tropics (CVI RFT) in some of the watershed studies in Kerala, showed that there is a need of reorientation of the policy with key on integration of socio-economic data sets with natural resource management.

The present study was carried out in parts of semiarid region of Pulivendula tehsil, Kadapa district, Andhra Pradesh (AP) with high degree of vulnerable to agricultural drought in the changing climate scenario. This is an ideal site to assess the degree to which natural ecosystems are pressured by deforestation and land use pressures that affect the vulnerability of agricultural systems. The potential agricultural zones for locally adopted crop production enhancing technologies will certainly influence on agrarian communities to maintain yields and conserve soil resources. The challenges of natural resource management in semi-arid regions of Rayalseema plateau with special reference to Pulivendula tehsil are off rugged and dissected terrains of different geological formations, high density of marginal farmer's and low input subsistence farming. The study was designed to integrate geoenvironmental assessment and the structure of rain fed agro ecosystem for development programs to provide strategic support to homogenous soil-crop zones. Some soil crop studies in the region were reported with respect to land evaluation for Groundnut (Rajendra Hegde et al., 2018) and aridity analysis (Bhaskar et al., 2019). Therefore, it becomes important to understand the relationship between the geoenvironmental assessment, and sensitivity of agro ecosystems (distribution among three cropping seasons, the ratio of cropped area to fallow area, percent fluctuation of cropped area) in different districts. The specific objectives of the present study are to identify and describe the important components of the different geopedological systems and agro ecosystems (system definition) in defining biophysical constraints and opportunities for agro management and development options.

\section{Description of the study area}

Pulivendula in Kadapa district $\left(14^{\circ} 16^{\prime}\right.$ to $14^{\circ} 44^{\prime} \mathrm{N}$ and $77^{\circ} 56^{\prime}$ to $\left.78^{\circ} 31^{\prime} \mathrm{E}\right)$ covers $1,46,235$ ha. This tehsil has six mandals namely: Pulivendula, Vemula, Vempalli, Tondur, Simhadripuram and Lingala (Figure 1). This study area is a part of semiarid climate with mean annual rainfall of $564 \mathrm{~mm}$ and 43 rainy days. The length of growing period (LGP) is varied from 90-105 days for Pulivendula and Vemula, 105-120 days for Lingala and Tondur and 120-135 days for Simhadripuram and Vempalli mandals. This area is moderately to marginally suitable for peanut cultivation under hot arid ecosubregion (K6E2) with deep loamy and clayey mixed red and black soils of Rayalseema plateau (Mandal et al., 1999). The terrain has rugged hills with valleys, severely eroded pediments and moderately to gently sloping pediplains. The study area is composed of the Papaghni and Chitravati group of rocks of Cuddapah 


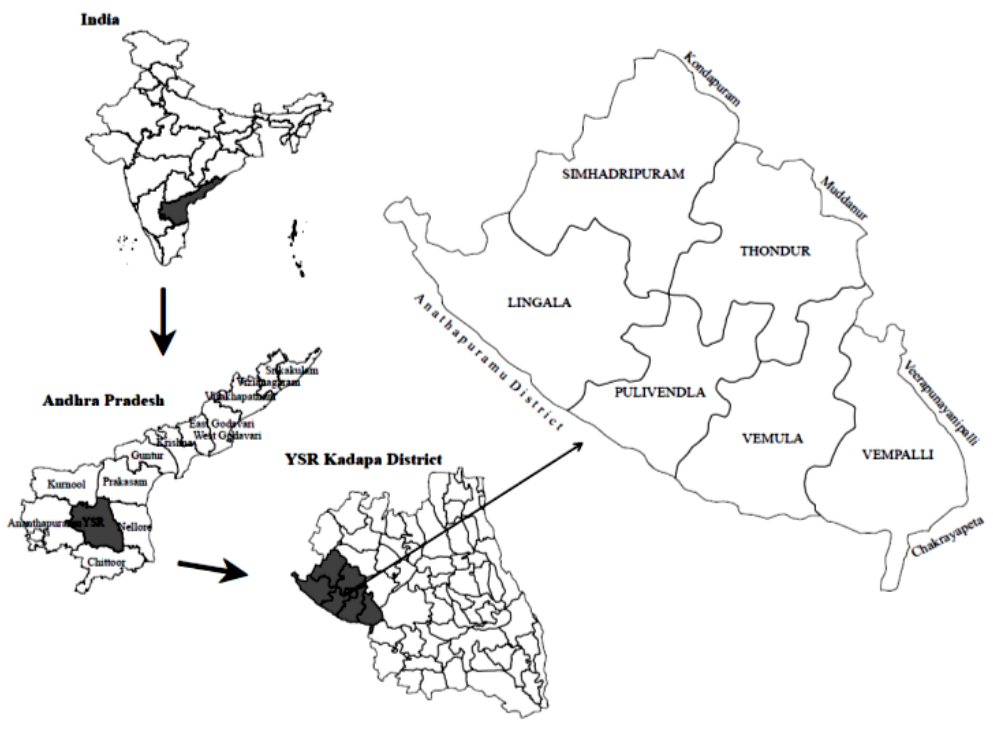

Figure 1. Location map of Pulivendula tehsil, Kadapa district, Andhra Pradesh.

Super Group. The rock types of Papaghni group consists of quartzite, arkose and conglomerates. The Chitravathi group of Vempalle formation consists of dolomites, chert, mudstone, quartzite, basic flows and intrusive rocks whereas quartzite with conglomerates of Pulivendula formation and shales, dolomite/quartzite of Tadipatri formations (Basu et al., 2009). Using remote sensing data of Indian Remote sensing satellite (IRS-P6-LISS-IV) data on 1:25000 scale, was used to delineate 9 broad landforms such as elongated ridges/cuseta (750-360m above mean sea level), dissected hills/summits, highly dissected plateau remnants, isolated hills/monad nocks/mounds/ tors/boulders/ domical rises/rock outcrops (54135ha of total area), interhill basins (6163ha of total area), undulating upper sectors, gently sloping middle sectors (39092ha of total area) and colluvial lower sectors (28542 ha of total area).

\section{Agroecosystem analysis}

The Agro ecosystem Analysis (AEA) was performed in three steps such as: I. agro climatic analysis (rainfall and temperature), II. geo-pedological data sets, and III. suitability of soil units for groundnut and banana under drip irrigation. The data integration of agroecosystem analysis was given in Figure 2 . Agroclimatic analysis of 20 years of data regarding area and productivity of groundnut / redgram and rainfall at district level (2000-2001 to 2018-2019) was collected from internet source (https:// aps.dac.gov.in). The bivariate plots were constructed and developed regression equations using Microsoft Excel 2007. The bivariate plots of rainfall versus productivity and area of groundnut and red gram were analysed. The bar diagram for south-west monsoon months were worked out. 
The agroecosystem has two components such as geo environmental setting and farmers' social / economic settings to adopt crop technologies.

Geoenvironmental settings: have systematic soil- landscape mapping agroecosystem boundaries and its functional relationships having subjective, locally-specific judgments about the defining elements of the agroecosystem.

Farm setting were defined on the basis of the dominant type of resource base and the dominant livelihood pattern of farm households (semistructured farmhouse interviews and local agricultural experts).
Step-1.Geoenvironmental assessment

Land resource data base (1:25000scale)

43 units soil map with physico-chemical properties

Step-2. Agroecosystem analysis
Agroclimatic analysis Aridity analysis Angot pluvial index

\section{Major crop zonation Ground nut based Banana based}

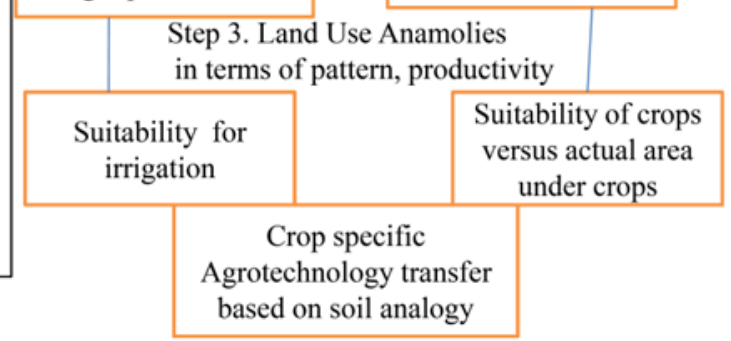

Figure 2. Relation of geopedological data with agroecosystem analysis in a part of Pulivendula.

\section{Geoenvironmenal assessment}

The semi detailed soil survey was carried out as per standard methodologies. The base was prepared using IRS-P6-LISS-IV (1:25000 scale) in conjunction with topographical and geological maps (1:50000 scale) of Pulivendula tehsil in Kadapa district (Figure 1). The semi detailed survey was carried out using geomorphological map as base for selection of transects and also random checks (Soil Survey Division Staff, 2017; Shalaby et al., 2017). The soil data comprises of both from field observations and laboratory data for major soil series in the region (Dent and Young, 1981; Grunwald, 2005). Sixty-six transects were selected and studied over 330 profiles (cut across as 3 to 4 landform units). 120 random checks were made to verify the occurrence of series in relation to landforms. The field work was partially confirmed with soil correlation work and their laboratory analyses. The morphological properties of twenty-five soil series were described as per Schoeneberger et al. (2012). The horizon wise soil samples were collected for major soil series. The samples were air-dried and passed through $2 \mathrm{~mm}$ sieve for fine earth fraction. The fine earth fraction was used for determination of both physical (particle size distribution) and chemical properties as per standard procedures (Dewis and Freitas, 1970). The soils were classified upto series level (Soil Survey Staff, 2014). These series are generally considered as carriers of soil information. Thereby, soil series associations were made as mapping units for soil survey interpretations. The soil map was generated in GIS environment (ARC info. Version 10). The soil survey data was compiled and published at a scale of 1:25,000 (Naidu et al., 2009). The soil erosion was computed for each soil mapping unit as per USLE (Wischmeier and Smith, 1978). Based on the values, these mapping units were categorized into 8 classes as: very low $=$ soil loss of $<0.5 \mathrm{t} / \mathrm{ha} /$ year, low $=0.5$ - 
$1 \mathrm{t} /$ ha/year, low-medium $=1-2 \mathrm{t} / \mathrm{ha} /$ year; medium $=2-5 \mathrm{t} /$ ha $/$ year; high-medium $=5-10 \mathrm{t} / \mathrm{ha} /$ year, high $=10-20 \mathrm{t} / \mathrm{ha} /$ year, very high $=20-50 \mathrm{t} / \mathrm{ha} /$ year and extremely high $=>50 \mathrm{t} / \mathrm{ha} /$ year. The land evaluation for banana and groundnut was made as per Sys et al. (1993). The parametric approach of Sys et al. (1993) was used to evaluate each mapping unit for their suitability to drip irrigation. The soil quality assessment was made as per the rating chart of Idowu et al. (2009). The scheme of rating chart for 11 soil variables was given in Table 1.

Table 1. Rating chart for soil quality index.

\begin{tabular}{|c|c|c|c|c|c|c|}
\hline \multirow{2}{*}{$\begin{array}{l}\text { Soil variable } \\
\text { Soil CEC/group }\end{array}$} & \multicolumn{5}{|c|}{ Values/rating } & \multirow{2}{*}{$\begin{array}{l}\text { Maximum } \\
\text { value }\end{array}$} \\
\hline & $<4.6(1)$ & $4.7-9.0 / 2$ & $9-15 / 3$ & $>15 / 4$ & & \\
\hline & 2 & 4 & 5 & 5 & & 5 \\
\hline \multirow[t]{2}{*}{ Soil pH } & $<5$ & $5.1-5.8$ & $5.9-7.0$ & $7.1-8.0$ & $>8$ & \\
\hline & 0 & 10 & 15 & 10 & 5 & 15 \\
\hline \multirow[t]{2}{*}{$P$ rating } & low & Medium & high & $\begin{array}{l}\text { Very } \\
\text { high }\end{array}$ & $\begin{array}{l}\text { Extremely } \\
\text { high }\end{array}$ & \\
\hline & 0 & 5 & 10 & 5 & 0 & 10 \\
\hline \multirow[t]{2}{*}{$\mathrm{K}$ rating } & low & Medium & high & $\begin{array}{l}\text { Very } \\
\text { high }\end{array}$ & $\begin{array}{l}\text { Extremely } \\
\text { high }\end{array}$ & \\
\hline & 0 & 5 & 10 & 8 & 5 & 10 \\
\hline \multirow{2}{*}{$\begin{array}{l}\text { Base saturation } \\
(\%)\end{array}$} & $<10$ & $11-25$ & $26-50$ & $51-75$ & $>75$ & \\
\hline & 0 & 3 & 6 & 10 & 8 & 10 \\
\hline \multirow{2}{*}{$\begin{array}{l}\text { Soil organic mat- } \\
\text { ter(\%) }\end{array}$} & $<1$ & $1.1-2.0$ & $2.1-3.0$ & $3.1-4.0$ & $>4.0$ & \\
\hline & 0 & 4 & 12 & 16 & 20 & 20 \\
\hline \multirow{2}{*}{$\begin{array}{l}\text { N mineralized } \\
(\mathrm{kg} / \mathrm{ha})\end{array}$} & $<11$ & $12-22$ & $23-45$ & $46-89$ & $>89$ & \\
\hline & 0 & 1 & 2 & 3 & 5 & 5 \\
\hline \multirow[t]{2}{*}{ Soil respiration } & Very low & low & moderate & high & Very high & \\
\hline & 0 & 1 & 2 & 3 & 5 & 5 \\
\hline \multirow[t]{2}{*}{$\begin{array}{l}\text { Aggregate stabil- } \\
\text { ity }\end{array}$} & $\begin{array}{l}\text { No aggre- } \\
\text { gates }\end{array}$ & weak & Moderate & Good & Very strong & \\
\hline & 0 & 2 & 4 & 6 & 8 & 8 \\
\hline \multirow{2}{*}{$\begin{array}{l}\mathrm{EC}\left(\mathrm{dSm}^{-1}\right) \\
1: 2 \text { soil water } \\
\text { ratio) }\end{array}$} & $<0.20$ & 0.21.- 0.4 & $0.41-0.80$ & $\begin{array}{l}0.81- \\
1.6\end{array}$ & $>1.6$ & \\
\hline & 3 & 5 & 3 & 2 & 0 & 5 \\
\hline \multirow[t]{3}{*}{ Metals } & \multicolumn{2}{|c|}{$\begin{array}{l}\text { Two or more metals } \\
\text { "very high" }\end{array}$} & \multicolumn{2}{|c|}{$\begin{array}{l}\text { One metal is very } \\
\text { high }\end{array}$} & $\begin{array}{l}\text { All metals } \\
\text { are opti- } \\
\text { mum }\end{array}$ & \\
\hline & \multirow{2}{*}{\multicolumn{2}{|c|}{-10}} & \multicolumn{2}{|l|}{-5.0} & 7 & 7 \\
\hline & & & \multicolumn{3}{|l|}{ Total } & 100 \\
\hline
\end{tabular}




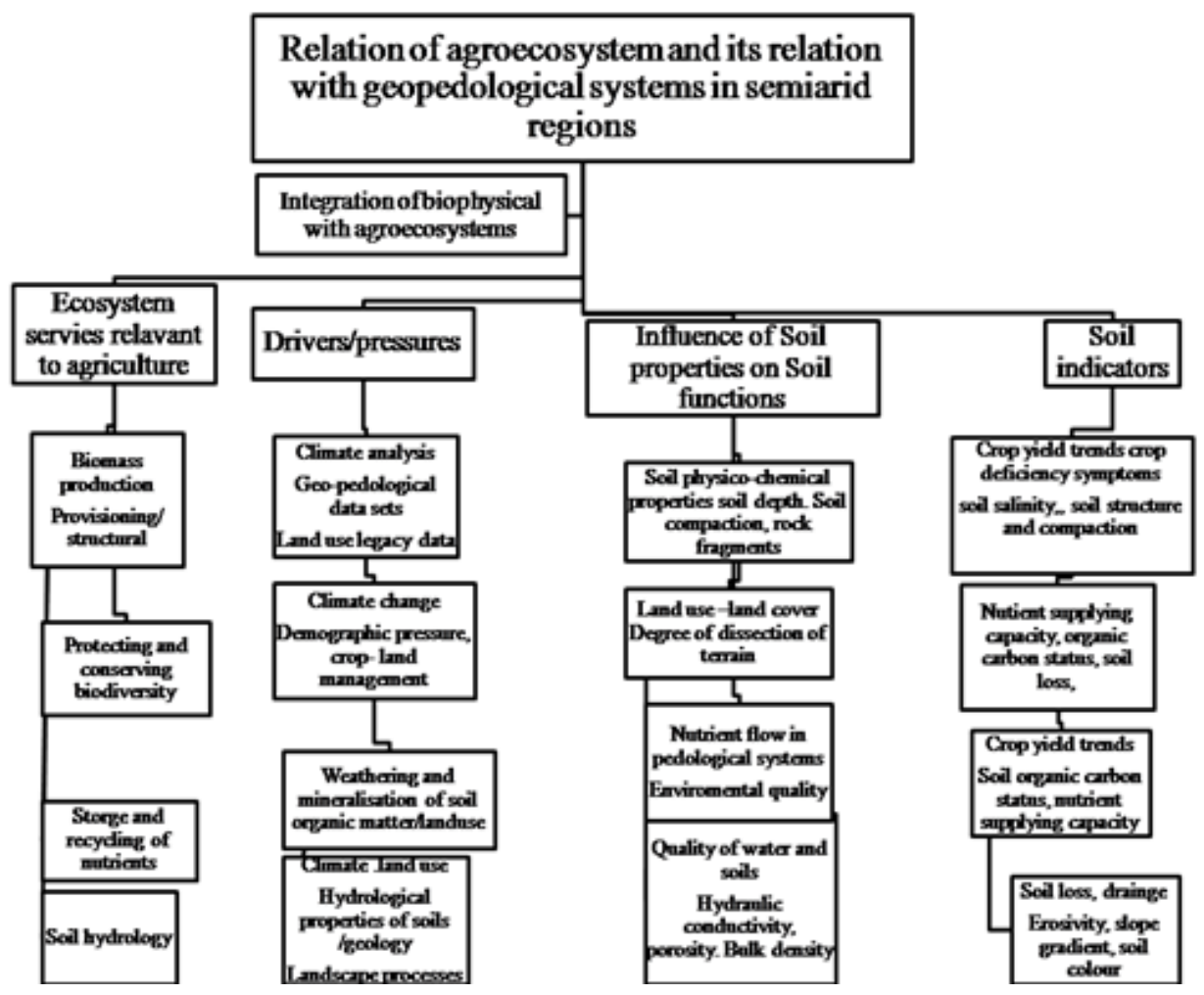

Figure 3. Relation of geopedological data with agroecosystem analysis in a part of Pulivendula.

Land use anomalies in terms of area and productivity

The geopedological data was integrated with existing agro ecosystems of Pulivendula tehsil, Kadapa district to know the anamolies in terms of land use. The framework was designed to address two key aspects of pedological systems such as soil capability (determined by the inherent, largely stable properties) that determine the natural limitations for crop productivity, (FAO, 1976, 2007; Dominati et al., 2010) and soil condition (determined by variables that reflect the soil status, and thus the current productivity). These two aspects (soil capability \& resilience) of geopedological data was used to assess the land potential and their susceptibility to degradation or change in the context of geomorphic setting (Oeh, 2012; Gray et al., 2015; Orr et al., 2017). The land suitability (FAO, 1976, 2007) was made to delineate suitable areas for specific and for monitoring soil condition under a defined set of land management practices of local importance. This scheme was partly adapted from the works of Lal (2016); Hazelton and Murphy (2016); Sangeda et al. (2014) but slightly modified to fit in the present study (Figure 3). 
Table 2. Statistical summary of year wise and seasonwise area and productivity of redgram and groundnut in Kadapa district (Source: https://aps.dac.gov.in)

\begin{tabular}{|c|c|c|c|c|c|c|c|c|c|c|}
\hline \multirow[t]{3}{*}{ Year } & \multicolumn{5}{|c|}{ Red gram } & \multicolumn{5}{|c|}{ Groundnut } \\
\hline & \multicolumn{3}{|c|}{ Area(ha ) } & \multicolumn{2}{|c|}{$\begin{array}{l}\text { Productivity (t/ } \\
\text { ha) }\end{array}$} & \multicolumn{3}{|c|}{ Area(ha ) } & \multicolumn{2}{|c|}{$\begin{array}{l}\text { Productivity (t/ } \\
\text { ha) }\end{array}$} \\
\hline & kharif & rabi & Total & $\begin{array}{l}\text { kha- } \\
\text { rif }\end{array}$ & rabi & kharif & rabi & Total & $\begin{array}{l}\text { kha- } \\
\text { rif }\end{array}$ & rabi \\
\hline $2000-2001$ & 15189 & 168 & 15347 & 0.55 & 0.55 & 150521 & 26324 & 176845 & 1.16 & 1.24 \\
\hline 2001-2002 & 12059 & 67 & 12126 & 0.59 & 0.6 & 119708 & 20282 & 139990 & 0.36 & 1.72 \\
\hline 2002-2003 & 15983 & 36 & 16019 & 0.16 & 0.17 & 87896 & 18282 & 106178 & 0.13 & 1.35 \\
\hline 2003-2004 & 29594 & 75 & 29669 & 0.3 & 0.31 & 109650 & 19746 & 129396 & 0.2 & 1.69 \\
\hline 2004-2005 & 18424 & 44 & 18424 & 0.26 & 0.25 & 201338 & 17604 & 218942 & 0.54 & 2.58 \\
\hline 2005-2006 & 16390 & 0 & 16390 & 0.27 & 0 & 184333 & 22988 & 207321 & 0.09 & 1.84 \\
\hline 2006-2007 & 9313 & 6 & 9319 & 0.16 & 0.17 & 46532 & 16080 & 62612 & 0.27 & 2.06 \\
\hline 2007-2008 & 14000 & 0 & 14000 & 0.29 & 0 & 145000 & 28000 & 173000 & 1.9 & 1.25 \\
\hline 2008-2009 & 10488 & 0 & 10488 & 0.08 & 0 & 124382 & 16630 & 141012 & 0.23 & 2.16 \\
\hline 2009-2010 & 12353 & 171 & 12524 & 0.17 & 0.17 & 111105 & 19013 & 130118 & 0.32 & 3.15 \\
\hline 2010-2011 & 19759 & 23 & 19782 & 0.29 & 0.3 & 143299 & 17296 & 160595 & 0.61 & 2.99 \\
\hline 2011-2012 & 8998 & 81 & 9079 & 0.25 & 0.25 & 36869 & 20188 & 57057 & 0.33 & 2.39 \\
\hline 2012-2013 & 10000 & 0 & 10000 & 0.1 & 0 & 44000 & 21000 & 65000 & 0.25 & 1.52 \\
\hline 2013-2014 & 8085 & 31 & 8116 & 0.3 & 0.29 & 42251 & 17263 & 59514 & 1.02 & 2.16 \\
\hline 2014-2015 & 2367 & 24 & 2391 & 0.15 & 0.17 & 15754 & 11588 & 27342 & 0.44 & 1.33 \\
\hline 2015-2016 & 7709 & 54 & 7763 & 0.4 & 0.41 & 28676 & 21983 & 50659 & 1.28 & 2.16 \\
\hline 2016-2017 & 17885 & 32 & 17917 & 0.2 & 0.19 & 52015 & 13396 & 65411 & 0.38 & 3.43 \\
\hline 2017-2018 & 8848 & 110 & 8958 & 0.3 & 0.3 & 25317 & 19056 & 44373 & 1.56 & 1.69 \\
\hline 2018-2019 & 4178 & 121 & 4299 & 0.14 & 0.14 & 8627 & 11113 & 19740 & 0.52 & 0.97 \\
\hline 2019-2020 & 4187 & 186 & 4373 & 0.35 & 0.35 & 8332 & 13495 & 21827 & 1.58 & 2.94 \\
\hline mean & 12290.4 & 61.4 & 12349 & 0.26 & 0.231 & 84280.2 & 18566.3 & 102846. & 0.66 & 2.03 \\
\hline sd & 6385.07 & 60.3 & 6372.7 & 0.13 & 0.178 & 60857.5 & 4381.04 & 63313.2 & 0.55 & 0.70 \\
\hline $\mathrm{CV}$ & 51.95 & 98.2 & 51.60 & 50.61 & 73.14 & 72.20 & 23.59 & 61.56 & 83.60 & 34.59 \\
\hline skewness & 0.85 & 0.93 & 0.86 & 1.02 & 0.49 & 0.40 & 0.28 & 0.36 & 1.07 & 0.49 \\
\hline kutosis & 1.46 & $-\overline{0}$ & 1.50 & 1.05 & 0.16 & -1.10 & 0.18 & -1.16 & -0.12 & -0.68 \\
\hline
\end{tabular}

\section{Agroecosystem analysis}

The agroecosystem analysis in Pulivendula tehsil is evaluated in terms of sustainability of groundnut (area and productivity trends)/red gram production systems. To justify the question of sustainability of agroecosystems, the time series data analysis is considered and discussed as below.

\section{Sustainability of groundnut/red gram in Kadapa district}

The data over 20 years (200-2001 to 2018-2019) on area and productivity of two principal crops, namely red gram and groundnut, is presented in Table 2. The data showed that the mean area under red gram is $12290.45 \pm 6385.07$ ha during kharif and $61.45 \pm 60.36$ ha during rabi. The coefficient of variation for area under kharif is $51.95 \%$ with mean productivity of $0.26 \pm 0.13 \mathrm{t} /$ ha and yield variation of 50.61 per cent. 

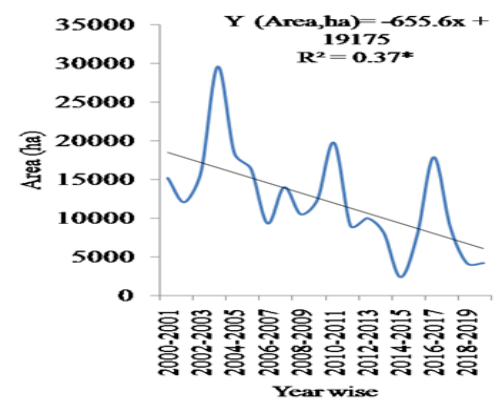

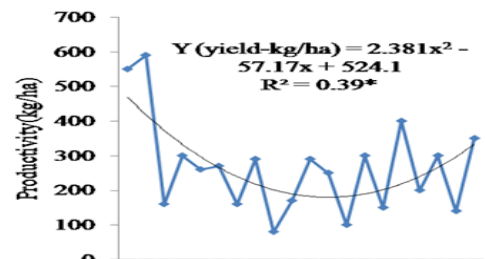

Figure 4. Area and Productivity of red gram during kharif (2000-01 to 2018-2019).
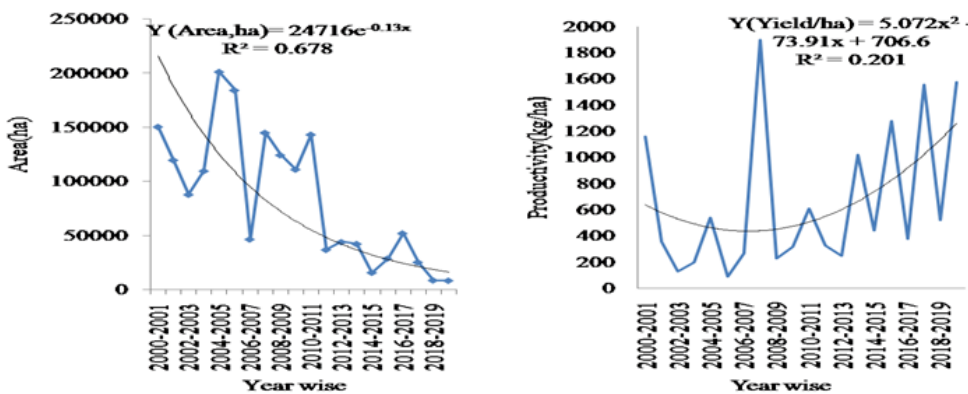

Figure 5. Yearwise area and productivity of Groundnut (2000-2001 to 2018-2019).

The productivity of red gram in kharif season in Kadapa is almost less than half to that of national average productivity ( $885 \mathrm{~kg} / \mathrm{ha}$ ). The mean area under kharif groundnut is $84280.25 \pm 60857.76$ ha with variation of 72.20 per cent but the area under rabi is $18566.35 \pm 4381.04$ ha with variation of 23.59 per cent. The mean productivity of kharif groundnut is $660 \pm 550 \mathrm{~kg} / \mathrm{ha}$ with variation of 83.60 per cent (national average yield of $1424 \mathrm{~kg} / \mathrm{ha}$ (Directorate of Economics and Statistics, 2017). The productivity of rabi groundnut is $2.03 \pm 0.7 \mathrm{t} /$ ha which is three times more to that of kharif groundnut. The skewness of area and productivity is less than +1 for red gram indicating substantially skewed but values less than 0.5 as noticed for groundnut indicating moderately skewed. The kurtosis is less than three indicating platykurtic with shorter and thinner tails (Hair et al., 2017). The graphs of area and productivity of kharif red gram shows that There is drastic decrease of area from 229954 ha during 20032004 to 4187 ha during 20019-2020 (Figure 4). The bivariate plot of area over years has yielded a linear regression equation with $\mathrm{R}^{2}$ (coefficient of determination) of $0.37^{*}(\mathrm{p}=0.05)$. The productivity graph over years has yielded a polynomial equation with $R^{2}$ of $0.39^{*}(p=0.05)$. Similar kind of graphs are constructed for groundnut where there is a significant reduction in area over a period of 20 years and yielded an exponential equation with $R^{2}$ value of $0.678^{* *}(p=0.01)$. The peak-sown area under groundnut is recorded during 2004-2005 covering 201338 ha but drastically decreased to less than 10000 ha during 2018 to 2020 (Figure 5). This data analysis undoubtedly raises the question of sustainability of groundnut production as there is a sudden drop in both area and productivity. 

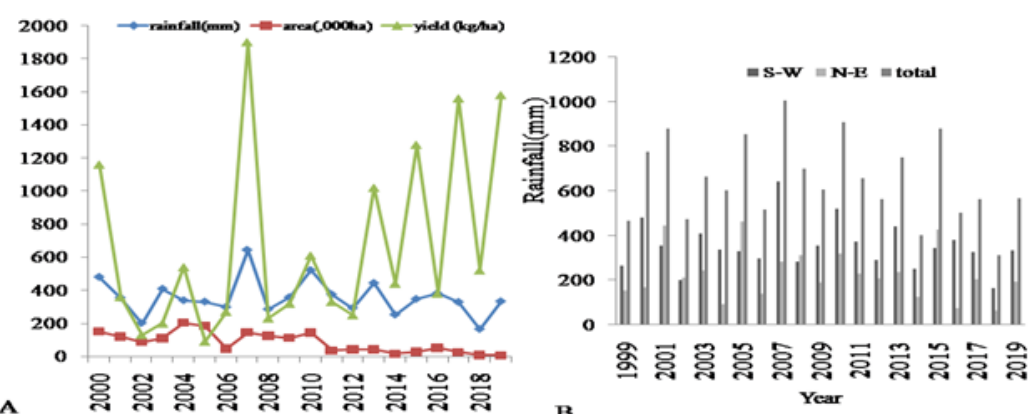

Figure 6. Relation of (A)south-west rainfall $(\mathrm{mm})$ with area and productivity of groundnut and contribution of S-W and N-E to total rainfall in Kadapa district.

\section{Relation of groundnut yield with rainfall}

The drought hit Pulivendula is really challenge to both crop planners and resource managers regarding the trends of groundnut shift and then to go for alternatives. Looking into the crisis of groundnut under rain fed, the rainfall analysis with main focus on seasonal dry spells during kharif is made in relation to productivity. The main focus is given for groundnut considering its area during kharif. Parmar (2013) reported a positive relation between amount of rainfall and yield of groundnut and expressed its relation in an equation as : Yield $=15.01+1.892$ June +2.301 July +1.582 August +0.648 September with $\mathrm{R}^{2}$ (coefficient of determination) of 0.48 .

The mean rainfall of the region is $650.6 \mathrm{~mm} \pm 183.8 \mathrm{~mm}$ and coefficient of variation of $28.2 \%$. There are only two seasons viz., South-West (S-W, June to September) and Northeast (N-E) monsoon. The S-W monsoon receives mean rainfall of $352.4 \pm 107.8 \mathrm{~mm}$ and shares $54.2 \%$ of total rainfall. The mean N-E monsoon receives $228.6 \pm 114.2 \mathrm{~mm}$ but shares $35.1 \%$ of total rainfall. The bivariate plot between rainfall and area under kharif groundnut has yielded power relation as Area (ha) $=8.03 *$ (rainfall, $\mathrm{mm}){ }^{1.53}$ with a coefficient of determination $\left(\mathrm{R}^{2}\right)$ of $0.303^{*}$ (significant at $5 \%$ level). The effect of rainfall on yield of groundnut has 3 rd order poly nominal equation $\left(R^{2}=0.363\right)$ significant at $5 \%$ level. These relations are depicted in Figure 6(A) and the contribution of S-W and N-E monsoon rains to total in Figure 6(B). The setting criteria for good groundnut harvest is to have minimum monthly rainfall of $100 \mathrm{~mm}$ and temperature of $21^{\circ} \mathrm{C}$ over the entire growing period (Cox, 1979, Varaprasad et al., 2000). The monthly decadal data of study area has De Martonne Aridity Index $\left(\mathrm{I}_{\mathrm{dm}}\right)$ below 15 to define climate as semiarid and needs irrigation in times of drought (Zambakas, 1992, Bhaskar et al., 2019). Under this type climatic conditions, Radha kumara et al. (2016) advocated to identify alternate remunerative crops to rain fed groundnut in Alfisols and able to produce about 5 to $10 \mathrm{~kg} / \mathrm{ha}$ of pods per millimeter of rainfall. For dry land peanuts, in the region an average rainfall of at least $400 \mathrm{~mm}$ from June to September is needed to produce a reliable crop. The long-term rainfall data shows a deficit of $60 \mathrm{~mm}$ during pod development phase (September, Bhaskar et al., 2019). Hence, the region experiences serious yield loss and reportedly low averge yields of groundnut. Thereby, the area under groundnut is drastically dropped to below 10000ha during 2018-2019. 


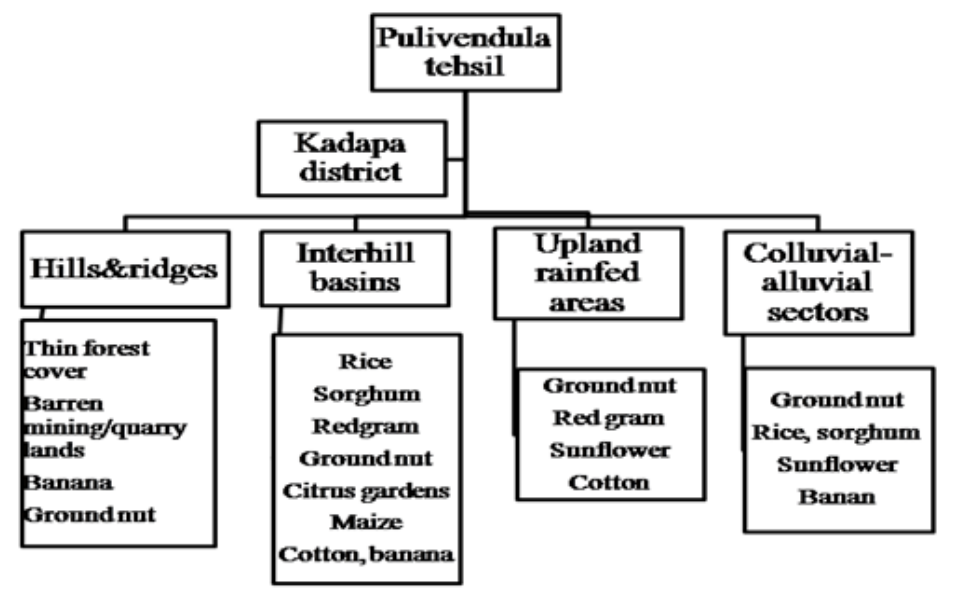

Figure 7. Agroecosystem hierarchy levels in Pulivendula tehsil, Kadapa district.

\section{Geoenvironmental assessment}

The geoenvironmental assessment is prerequisite for restructuring semiarid agro ecosystems experiencing serious economic losses. The two ways of geopedological analysis in relation to agro ecosystems on land use decisions depends on the geopedological knowledge used to understand the kind of ecological functions and services to the locals under a define sets of social-cultural context and application of soil-landscape knowledge for scientific transferring of agro technology.

At first, the subject of agro ecosytem deals with hierarchy of agri resource information in defining ecosystems of a region (Figure 7). Broadly, the Pulivendula tehsil has four distinct ecosystems such as hills/ridges, interhill basins, upland upper sectors and colluvio-alluvial sectors. The visual interpretation of IRS-P6-LISS-IV data on 1:25000 scale, revealed 4 broad landforms. The data shows that hills/ridges cover 54135 ha of total area followed by undulating upper sectors (39092 ha), colluvial lower sectors (28542 ha) and interhill basins (6163 ha). Among four landforms, 32.8 percent of area is under hills and ridges whereas 36.82 per cent of area is under undulating upper sectors used for groundnut based cropping systems. The groundnut grown in shallow stony red soils of hills and ridges and undulating upper sectors experiences severe water stress and incur serious crop loss during drought periods. The colluvial-alluvial sectors (22 per cent of area) and interhill basins (4.68\%) are extensively used for banana and citrus cultivation. The cropping systems mentioned in flow chart (Figure 7) are commonly grown under different landscapes of varied geological formations in the region. The results on mixed cropping sorghum/pigeon pea/groundnut/cotton/bengal gram are more economically enumerative as against low productive monoculture of groundnut (Bhaskar et al., 2019). The field photo's of agricultural landscapes at study site showed that hills are open and fully exposed to different degrees of erosion. The hills are mostly covered with stony surface cover (Figure 8). The field photos shows that locals are not paying due attention on conserving and protecting the biodiversity in geological landscapes. Now-a-days, the upland sectors in western parts of tehsil are intensively used for commercial production of banana under drip system but the ploughed for 
A

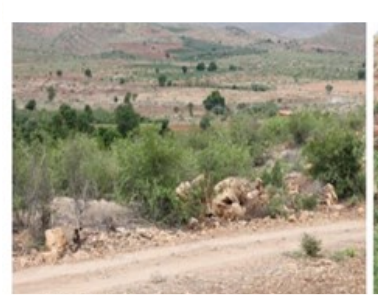

ii

iii
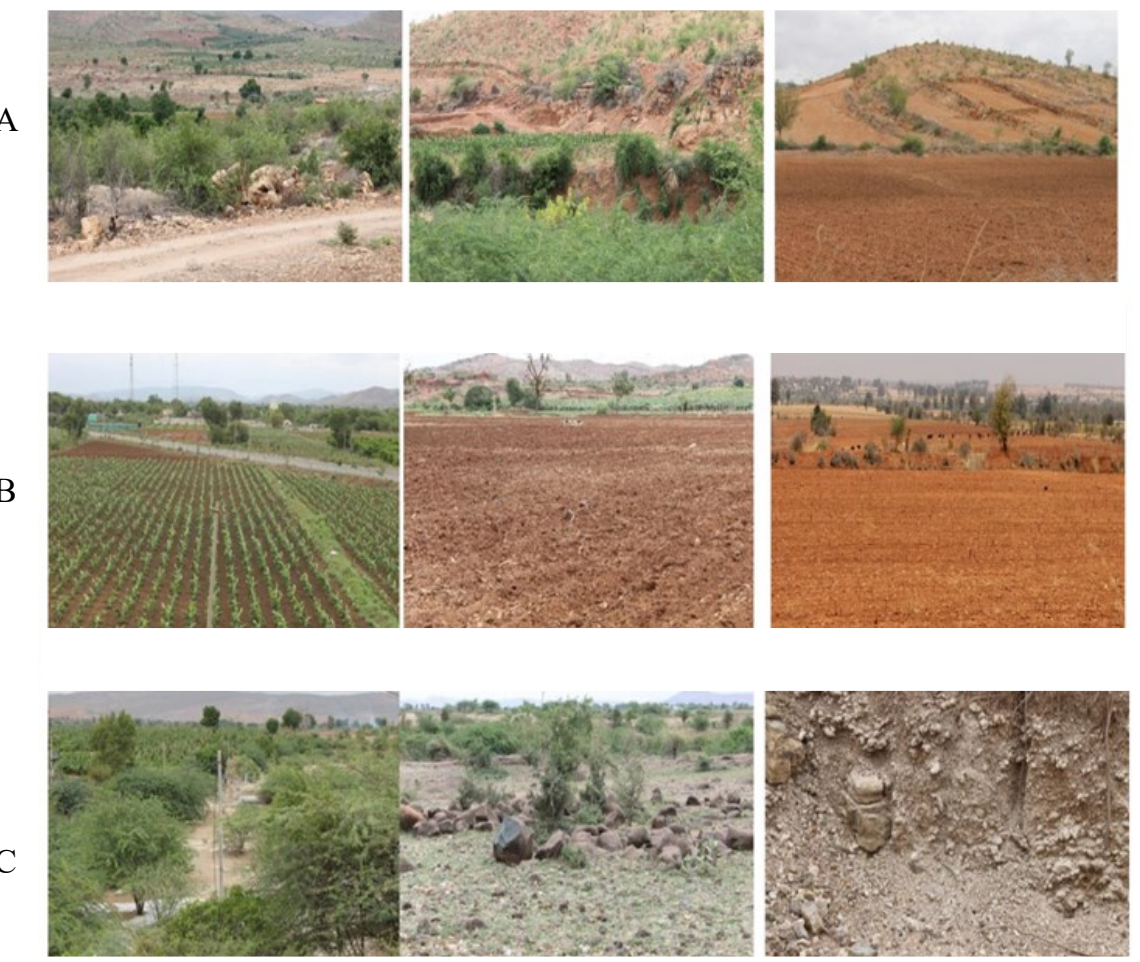

Figure 8. View of landforms (A).hills and ridges -i.dolomitic hills with thin vegetation cover, ii.quartzitic hills with thin forest cover and gravelly surface and iii. Hills with rock bunding made for banana cultivation (B). undulating upper sectors -i. banana field under drip system of irrigation, ii. Prepared for sowing groundnut and iii. dry fields during summer, (C) colluvio-alluviall sectors- i.badly managed stream floors, ii. Severely dissected rocky surfaces and iii. Cut off and exposed river banks enriched with lime content.

groundnut in red soils during kharif. The neglected parts of colluvio-alluvial sectors are heavily infested with Prosopis and have surface salt encrustations and calcium carbonate concretions in subsoil's. The agricultural land use is mostly groundnut as major but, banana and rice is grown under irrigation in interhill/colluvio-alluvial sectors (Figure 9). The field evidences strongly advocate adopting agro ecology principles in the region with a view to optimizing nutrient cycling, productivity of crops over time (Conway, 1985) and enhancing soil biological activity at landscape level (Altieri et al., 2015). This region is technically defined as "production syndrome" with a defined set of management practices (Andow and Hidaka, 1989) that are mutually less adaptive and not explained by the additive effects of individual practices. 

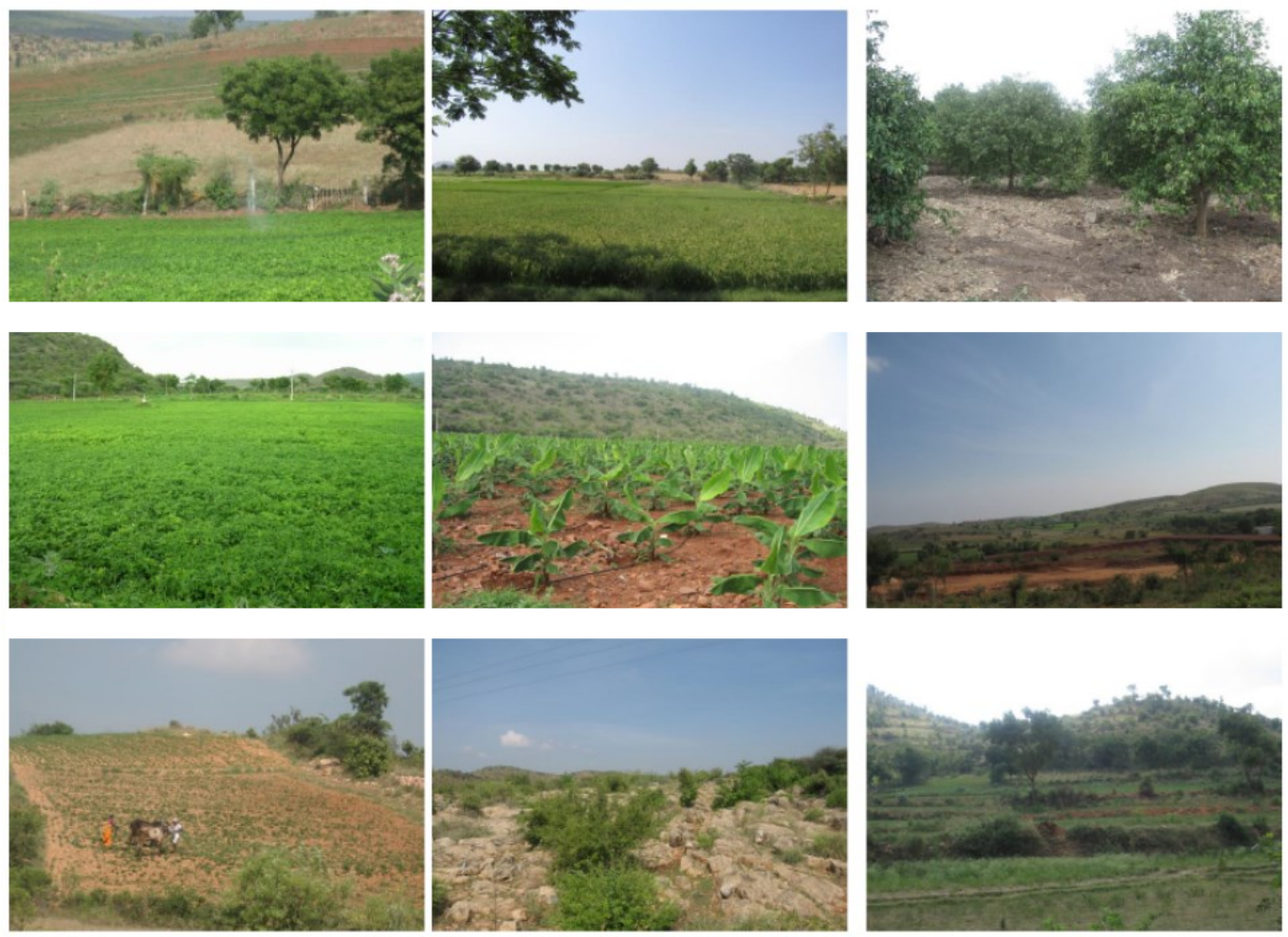

Figure 9. Monoculture of land use systems in Pulivendula tehsil.

\section{Textural and chemical characteristics of soil series}

The soils on quartzitic landforms have mean $\mathrm{pH}$ of (P1 to P5) $7.68 \pm 0.68$ with coefficient of variation of 7.99 per cent but, soils on shale's have mean of $8.01 \pm 0.2$ with coefficient of variation of 2.47 (Table 3). It had been reported that the slightly alkaline upland soils with a $\mathrm{pH}$ up to 8.0 in Pulivendula are evaluated as suitable for groundnut (Vara Prasad et al., 2000). The Pulivendula series (P21) has low organic carbon of $2.6 \mathrm{gkg}^{-1}$ but more than $10 \mathrm{gkg}^{-1}$ in case of P8, P13, and P19 with mean of $7.26 \pm 3.13 \mathrm{gkg}$ -1 . The mean organic carbon in quartzitic soils is $13.58 \pm 4.24 \mathrm{gkg}^{-1}$. These soils have medium to high status of organic carbon and can be used for sustainable groundnut production (Hazelton and Murphy, 2007). Four groups of soils are identified based on CEC. Seventy two per cent of soils per cent of soils have high $(48 \%)$ to very high CEC (24\%). The remaining $28 \%$ soils are grouped under low $(12 \%)$ to moderate CEC $(16 \%)$. These soils have calcium carbonate $\left(\mathrm{CaCO}_{3}\right)$ content of $10 \mathrm{~g} / \mathrm{kg}$ in P1 to $160 \mathrm{~g} \mathrm{~kg}^{-1}$ in P12. The appearance of calcic layer in support $\mathrm{CaCO}_{3}$ content is used to classify Vemula series (P12) under the subgroup of Calcic Haplustalfs. The calcium carbonate content is generally low in quartzitic soils (mean of $20 \pm 10 \mathrm{gkg}^{-1}$ ) but relatively more in soils on shale (mean of $87.62 \pm 46.57 \mathrm{~g} / \mathrm{kg}$ ). It is observed during soil surveys that the soils of interhill basin and colluvial alluvial complex have higher 


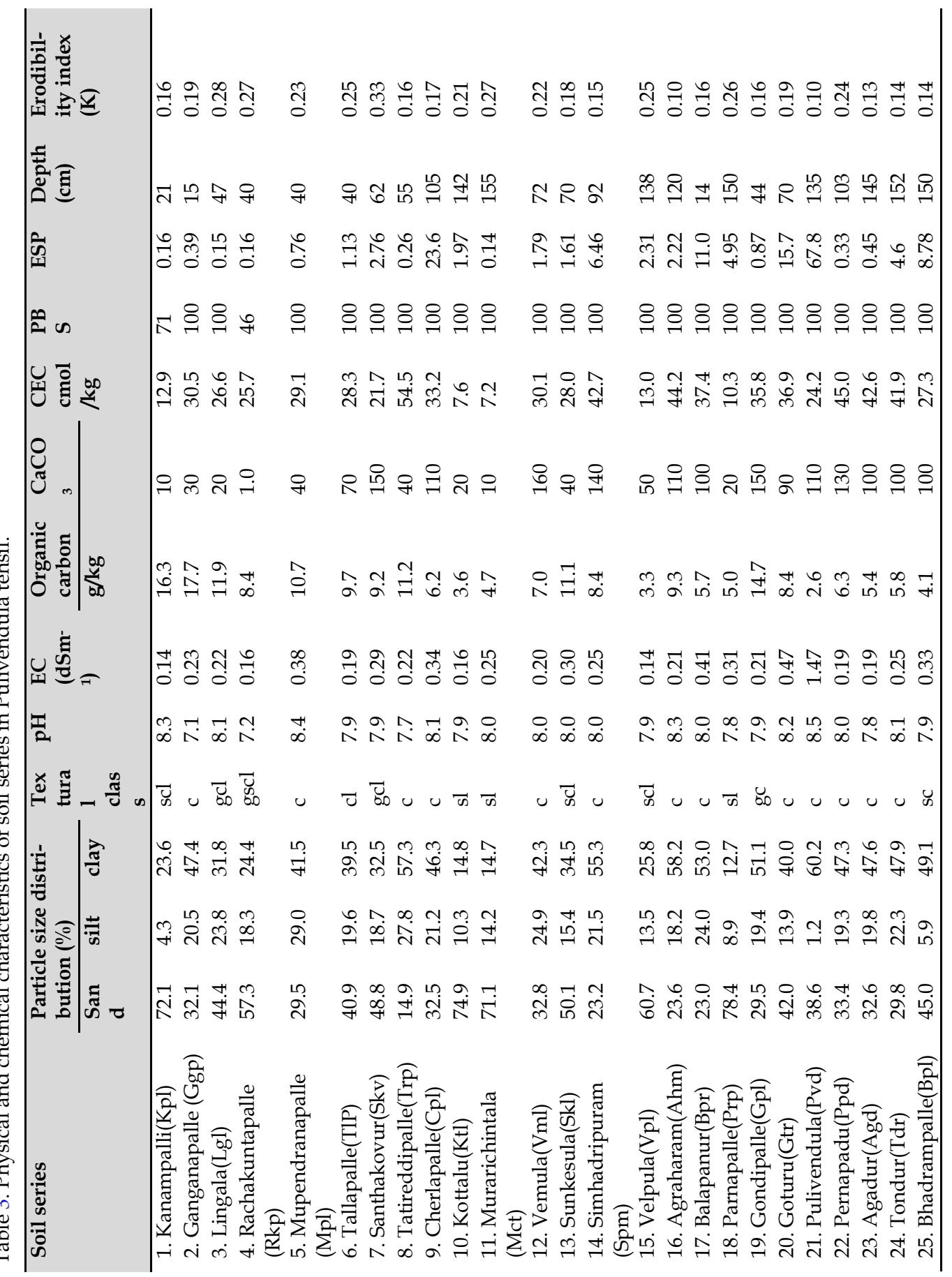


$\mathrm{CaCO}_{3}$ contents due to restricted internal drainage and high degree of aridity. This observation is in agreement with reports of Bhaskar et al. (2015). The per cent base saturation is more than 100 per cent. Generally these soils have less than 15 per cent of exchangeable sodium per cent except P9, P20 and P21. The Cherlapalle (P9), Gottur (P20) and Pulivendula series (P21) are classified under the subgroups of Sodic Ustic Haplocambids considering the ESP more than $15 \%$ in subsoils. The erodibility index (K) less than 0.2 indicates no susceptibility to water erosion. The 14 series comes under this category viz., Kanampalli(Kpl), Ganganapalle(Ggp), Tatireddipalle(Trp), Cherlapalle(Cpl), Sunkesula(Skl), Simhadripuram(Spm), Agraharam(Ahm), Balapanur(Bpr), Gondipalle(Gpl), 20.Goturu(Gtr), Pulivendula (Pvd), Agadur(Agd), Tondur(Tdr) and Bhadrampalle(Bpl). The remaining 11 series have K values of 0.2 to 0.3 indicating weakly susceptible to water erosion (Vopravil et al., 2007).

Among soil properties, the soil organic carbon shows significant variation between the landforms with $\mathrm{F}$ value of 5.08 ( $\mathrm{p}=0.008)$. The results of turkey test further show that there is an absolute mean difference of 7.142 with marginal error of 5 at $95 \%$ turkey interval. The comparative mean between colluvio-alluvial sector to that of hills/ridges shows significant variation with mean of $0.0943 \pm 0.0874$. Similar sort of exercise performed for soil depth that shows significant variation between landforms with $F$ value of 7.95 ( $p=0.001)$. The turkey results show that there is a significant mean difference of $60.85 \pm 53.4 \mathrm{~cm}$ between interhill basins and hills/ridges. Like wise, there is a significant mean difference $99.14 \pm 58.54 \mathrm{~cm}$ between colluvio-alluvial sectors and hills/ridges.

\section{Soil mapping}

Twenty five soil series are identified after field correlation and designed 43 mapping units as series association (Figure 10). Among 43 soil mapping units, eight mapping units are associated with hills/ ridges having rock outcrops and shale rock type. The sandy loam to clay loam soils in these units are very shallow, somewhat excessively drained and moderately alkaline. The eight soil mapping units cover 54812 ha $(42.62 \%$ of total area, Table 4$)$.

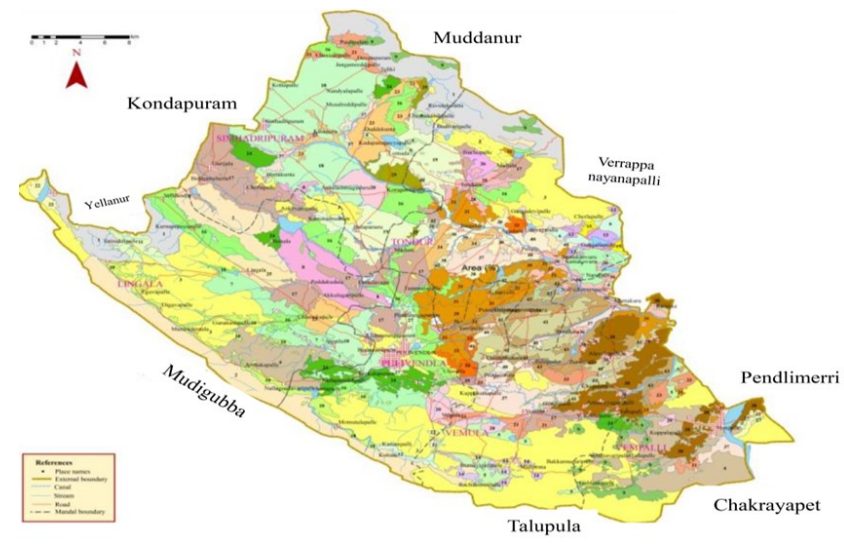

Figure 10. Soil map of Pulivendula tehsil, Kadapa district (Number in mapping units and its description is given in Table 3 ). 
Table 4. Area and extent of soil-land form associations.

\begin{tabular}{|c|c|c|c|c|c|}
\hline \multirow[t]{2}{*}{ Land form } & \multirow[t]{2}{*}{ Soil mapping unit } & \multicolumn{2}{|l|}{ Area } & \multirow{2}{*}{$\begin{array}{l}\text { Soil loss }(t / \text { ha/year }) / \\
\text { soil erosion risk }\end{array}$} & \multirow[t]{2}{*}{ SQ1 } \\
\hline & & $\begin{array}{l}\text { ha } \\
\text { (hect } \\
\text { ares) }\end{array}$ & $\begin{array}{l}\text { Per } \\
\text { cent } \\
(\%)\end{array}$ & & \\
\hline \multirow[t]{9}{*}{$\begin{array}{l}\text { Hills and } \\
\text { ridges }\end{array}$} & $\begin{array}{l}\text { 1. Rockoutcrops ( R)-Kanampalli } \\
(\mathrm{Kpl})\end{array}$ & 7953 & 6.18 & 25.11/high & 18 \\
\hline & $\begin{array}{l}\text { 2. Rockoutcrops }{ }^{\circledR}-\text {-Ganganapalle } \\
\text { (Ggp) }\end{array}$ & 7464 & 5.80 & 57.94/high & 20.8 \\
\hline & 3. Rockoutcrops ${ }_{-}$ & 2493 & 19.39 & 9.91/high-medium & 16 \\
\hline & Rachanakuntapalle(Rkp) & 9 & & & \\
\hline & 4. Rockoutcrops ${ }^{\circledR--L i n g a l a(L g l) ~}$ & 6410 & 4.98 & $\begin{array}{l}\text { 102.80/extremely } \\
\text { high }\end{array}$ & 18.8 \\
\hline & $\begin{array}{l}\text { 5. Rachanakuntapalle(Rkp) - rock- } \\
\text { outcrops® }\end{array}$ & 1333 & 1.04 & 8.93/high medium & 24 \\
\hline & $\begin{array}{l}\text { 6. Ganganapalle(Ggp)- } \\
\text { Rockoutcrops } ®\end{array}$ & 677 & 0.53 & 57.94/ extremely high & 31.2 \\
\hline & $\begin{array}{l}\text { 7. Rockoutcrops }{ }^{\circledR}-\text { Mupendranpalle } \\
(\mathrm{Mpl})\end{array}$ & 3572 & 2.78 & 8.6/high medium & 15.6 \\
\hline & $\begin{array}{l}\text { 8. Mupendranpalle(Mpl)- Rockout- } \\
\text { crops }{ }^{\circledR}\end{array}$ & 2464 & 1.92 & 8.56/ high medium & 23.4 \\
\hline \multirow{11}{*}{$\begin{array}{l}\text { Interhill ba- } \\
\text { sin }\end{array}$} & 9. Tallalapalle(Tlp) & 1829 & 1.42 & 8.97/ high medium & 42 \\
\hline & 10. Murarichintla(Mct) & 1934 & 1.50 & $8.90 /$ high medium & 49 \\
\hline & 11. Tatireddipalle(Trp) & 788 & 0.61 & 1.33/low medium & 47 \\
\hline & 12. Kottalu(Ktl) & 372 & 0.29 & 3.46/ medium & 37 \\
\hline & 13. Santhakovur(Skv) & 548 & 0.43 & 11.84/high & 44 \\
\hline & $\begin{array}{l}\text { 14. Murarichintala(Mct)-Tallapalle } \\
\text { (TIP) }\end{array}$ & 508 & 0.39 & 8.92/ high medium & 46.2 \\
\hline & 15. Cherlapalle(Cpl) & 184 & 0.14 & 5.27/ high medium & 46 \\
\hline & 16. Balapanur(Bpr) & 6559 & 5.10 & $24.23 /$ very high & 52 \\
\hline & 17. Simhadripuram(Spm) & 7583 & 5.90 & 1.82/low-medium & 54 \\
\hline & $\begin{array}{l}\text { 18. Simhadripuram(Spm)- Agra- } \\
\text { haram(Ahm) }\end{array}$ & 9125 & 7.10 & $2.68 /$ medium & 55.6 \\
\hline & 19. Balapanur(Bpr)-Sunkesula(Skl) & 4294 & 3.34 & $3.65 /$ medium & 54 \\
\hline \multirow{9}{*}{$\begin{array}{l}\text { Upland rain- } \\
\text { fed areas }\end{array}$} & 20. Vemula $(\mathrm{Vml})$ & 1667 & 1.30 & 7.65/ high medium & 57 \\
\hline & 21. Velpula(Vpl) & 1326 & 1.03 & $4.12 /$ medium & 58 \\
\hline & 22. Parnapalle(Prp) & 446 & 0.35 & 1.36/low-medium & 59 \\
\hline & 23. Agraharam(Ahm) & 2690 & 2.09 & $3.59 /$ medium & 58 \\
\hline & 24. Sunkesula(Skl) & 2778 & 2.16 & 2.97/ medium & 57 \\
\hline & $\begin{array}{l}\text { 25. Agraharam(Ahm)-Sunkesula } \\
\text { (Skl) }\end{array}$ & 802 & 0.62 & $3.61 /$ medium & 57.6 \\
\hline & $\begin{array}{l}\text { 26. Agraharam(Ahm)- } \\
\text { Simhadripuram(Spm) }\end{array}$ & 369 & 0.29 & $2.78 /$ medium & 56.4 \\
\hline & $\begin{array}{l}\text { 27. Sunkesula(Skl)-Simhadripuram } \\
(\mathrm{Spm})\end{array}$ & 741 & 0.58 & $2.65 /$ medium & 55.8 \\
\hline & 28. Velpula(Vpl)-.Vemula(Vml) & 712 & 0.55 & 5.36/high medium & 57.6 \\
\hline
\end{tabular}


Table 4. Continued...

\begin{tabular}{|c|c|c|c|c|c|}
\hline \multirow[t]{2}{*}{ Land form } & \multirow[t]{2}{*}{ Soil mapping unit } & \multicolumn{2}{|l|}{ Area } & \multirow{2}{*}{$\begin{array}{l}\text { Soil loss (t/ha/year) / } \\
\text { soil erosion risk }\end{array}$} & \multirow[t]{2}{*}{ SQ1 } \\
\hline & & $\begin{array}{l}\text { ha } \\
\text { (hect } \\
\text { ares) }\end{array}$ & $\begin{array}{l}\text { Per } \\
\text { cent } \\
(\%)\end{array}$ & & \\
\hline \multirow{16}{*}{$\begin{array}{l}\text { Colluvial- } \\
\text { alluvial pedi- } \\
\text { plains }\end{array}$} & $\begin{array}{l}\text { 29. Bhadrampalle(Bpl)- Agadur } \\
\text { (Agd) }\end{array}$ & 788 & 0.61 & 19.34/high & 55.2 \\
\hline & 30. Tondut(Tdr)-Pernapadu(Ppd) & 1351 & 1.05 & 85.36/ extremely high & 53.6 \\
\hline & 31. Tondur(Tdr) & 3568 & 2.77 & $\begin{array}{l}\text { 102.80/ extremely } \\
\text { high }\end{array}$ & 56 \\
\hline & 32. Agadur(Agd) & 633 & 0.49 & $1.86 /$ low -medium & 54 \\
\hline & $\begin{array}{l}\text { 33. Pernapadu(Ppd)-Gondipalle } \\
(\mathrm{Gpl})\end{array}$ & 853 & 0.66 & 5.68/high -medium & 58.8 \\
\hline & 34. Tondur(Tdr)-Agadur(Agd) & 709 & 0.55 & 90.56/ extremely high & 55.2 \\
\hline & $\begin{array}{l}\text { 35. Pulivendula(Pvd)-Pernapadu } \\
\text { (Ppd) }\end{array}$ & 101 & 0.08 & 15.32/high & 50 \\
\hline & 36. Goturu(Gtr)-Gondipalle(Gpl) & 1501 & 1.17 & 2.75/low-medium & 63 \\
\hline & 37. Pernapadu(Ppd) & 3689 & 2.87 & 17.31/high & 50 \\
\hline & 38. Pernapadu(Ppd)- Tondur(Tdr) & 4358 & 3.39 & 85.36/ extremely high & 52.4 \\
\hline & 39. Gondipalle(Gpl) & 1683 & 1.31 & $3.10 /$ medium & 72 \\
\hline & 40. Goturu(Gtr) & 1707 & 1.33 & 1.33/low-medium & 57 \\
\hline & 41. Agadur(Agd)- Pernapadu(Ppd) & 3613 & 2.81 & 15.36/high & 52.4 \\
\hline & 42. Bhadrampalle(Bpl)- & 448 & 0.35 & $24.23 /$ very high & 56 \\
\hline & 43. Pulivendula(Pvd) & 3540 & 2.75 & 17.31/high & 50 \\
\hline & Total & $\begin{array}{l}1286 \\
09\end{array}$ & 100 & & \\
\hline
\end{tabular}

The undulating uplands cover 39092 ha (30.4\% of area) with 12 soil mapping units. The moderately shallow, well drained Vemula soils (20-1,667 ha, 1.2\%) are calcareous and strongly alkaline with clay surface texture and gravelly clay subsoil. The mapping units namely Velpula soils (21- 1,326 ha, 1.0\%), Parnapalle in Lingala mandal (22- 446 ha, 0.3\%), Velpula-Vemula association in Tondur mandal are widely occurring (28-712 ha, 0.5\%). This mapping unit is associated with deep, moderately well drained, calcareous, strongly to moderately alkaline black soils with high shrink-swell potentials. Soils of colluvic and alluvial plains cover 28542 ha (22.19\% of total land area) with series association of Tondur-Pernapadu (30), Pernapadu-Gondipalle association (33), Goturu-Gondipalle association (36) and Agadur-Pernapadu association (41).

\section{Estimation of soil erosion}

The annual soil loss was estimated by integrating rainfall erosivity, soil erodibility, topography, cover management, and supporting factors as used in USLE. Six classes of soil erosional mapping units are identified in the study area (Table 4). Based on area estimations, the soil erosion risk zones are arranged in ascending order as : high-medum (39142 ha, 31.16\%) > high (276696 ha, 22.05\%) > medium (23378 ha, $18.6 \%)>$ extremely high (16364 ha, 13.03\%) > low-medium (12025 ha, 9.57\%) > very high (7007 ha, 
$5.58 \%$ ).when data arranged as per landform wise, three soil erosion risk zones are delineated viz., highmedium, high and extremely high in hills and ridges. The high-medium soil loss zone covers 32308 ha (25.13\% of total area) followed by 15417ha under high erosion risk zone $(11.98 \%)$ and off 7087 ha (5.51\%) under extremely high erosion risk zone. The mean soil loss $34.97 \pm 34.75 \mathrm{t} / \mathrm{ha}$ /year to categorize as very high erosion risk zone in hills and ridges due to high LS factor and slope gradient > $30 \%$. The interhill basin has 20 soil mapping units covering $35.19 \%$ of total area (45255 ha) with soil loss of $115 \mathrm{t} / \mathrm{ha}$ /year. The mean soil loss is $10.96 \mathrm{t} / \mathrm{ha}$ /year to categorize as high erosion risk with a deviation of $23.82 \mathrm{t} / \mathrm{ha}$ /year. Out of 20 SMUs, 7 are categorized as medium erosion risk zone with mean soil loss of $3.25 \pm 0.55 \mathrm{t} / \mathrm{ha}$ /year. The estimated area under medium class is $22497 \mathrm{ha}$ ( $17.5 \%$ of total area). The six SMUs under high-medium class covers $6843 \mathrm{ha}(5.3 \%)$ with mean soil loss of $12.87 \pm$ $12.87 \mathrm{t} / \mathrm{ha} /$ year. This class has sum of soil loss of $45.07 \mathrm{t} / \mathrm{ha} /$ year. Only three SMUs are categorized under low-medium erosion risk zones with total soil loss of $4.51 \mathrm{t} / \mathrm{ha} /$ year in an area of $8817 \mathrm{ha}$ (6.86\% of total area). The mean soil loss is $1.503 \pm 0.27 \mathrm{t} / \mathrm{ha}$ /year with variation of 18.26 per cent. The SMU Balapanur (16) is classified as very high erosion risk zone covering 6559 ha (5.1\%) and Santhakovur (13) under high-risk covering 548 ha $(0.43 \%)$. This landscape unit is mostly used for groundnut-banana based cropping systems in the region wherein crop management factor and soil erodibility factor decides the differential rates of erosional status. The fifteen SMUs in colluvial- alluvial pediplains cover 28542 ha $(22.19 \%)$ with total soil loss of $487 \mathrm{t} / \mathrm{ha} /$ year and mean of $32.45 \pm 37.39 \mathrm{t} / \mathrm{ha} / \mathrm{yr}$. The five SMUs under high erosion risk cover 11731 ha (9.12\%) with a total soil loss of $84.64 \mathrm{t} / \mathrm{ha} / \mathrm{yr}$ and mean of $16.92 \pm 1.66 \mathrm{t} / \mathrm{ha} / \mathrm{yr}$. The four SMUs in colluvial-alluvial pediplains are classified under extremely eroded zone and covers 9986 ha $(7.76 \%)$ with the total soil loss of $364 \mathrm{t} / \mathrm{ha} / \mathrm{yr}$ and mean of $91.02 \pm 8.23 \mathrm{t} /$ ha/yr. The per cent area under low-medium erosion class is 1.66 (2134ha) and of high-medium erosion class in Pernapadu-Gondipalle (33) unit with an area of $853 \mathrm{ha}(0.66 \%)$. The variation in the results may be attributed to the varying soil factors in the different landscape units. In the study area, as expected, high erosion rate was recorded in the steeper slope area that ranges from 30 to $83 \%$ and the use of agricultural lands. The focus is for soil conservation practices in highly eroded areas. Due attention must be given for sustainable land management strategies considering the terrain attributes, status of land use cover and interest of the local community. Agroforestry, terracing, cut and carry system can be integrated to manage erosion prone areas of steep hills of Palakonda range of Pulivendula.

\section{Soil quality assessment}

The SQIs for every soil mapping unit of Pulivendula tehsil are figured out and presented in Table 4. These soils are grouped as High (\% Q rating > 65), medium (\% Q rating 35 to 65$)$ and low ( $<35 \% \mathrm{Q}$ rating). The hills and ridges have 8 units with medium SQI values. The soil units have an association of shallow soils with rock outcrops. Twenty two soil units in inter hill basin are rated as medium to high quality. The soils in this landform show a strong positive correlation of $\mathrm{pH}$ with exchangeable Ca due to calcareousness. In colluvio-alluvial sectors, 15 units are evaluated as medium level of soil quality with parameters viz., soil $\mathrm{pH}, \mathrm{Zn}$ and Olsen's $\mathrm{P}$ below critical level and remaining units are rated as high. 


\section{Land use anomalies and site-specific suitability}

\section{Suitability for Groundnut (Arachis hypogeae)}

The suitability evaluation for groundnut shows that only 23 soil mapping units are moderately suitable (Table 5) with the restrictions of rooting depth (r), topography ( $\mathrm{t}$ ) and salt content $(\mathrm{z})$. The moderately suitable soil mapping units cover 56224ha (43\% of total area) consisting of 13 soil consociations (31501 ha, $24.49 \%$ of total area) and 10 soil associations ( $24723 \mathrm{ha}, 19.22 \%$ of total area). The suitability analysis shows that $43 \%$ of total area is good for groundnut cultivation. This crop is extensively cultivated in

Table 5. Soil-site suitability for Groundnut.

\begin{tabular}{|c|c|c|c|c|}
\hline \multirow[t]{2}{*}{$\begin{array}{l}\text { Suitability } \\
\text { subclass }\end{array}$} & \multirow[t]{2}{*}{ Landform } & \multirow[t]{2}{*}{ Soil mapping unit } & \multicolumn{2}{|c|}{$\begin{array}{l}\text { Ground nut } \\
\text { area }\end{array}$} \\
\hline & & & ha & $\%$ \\
\hline \multirow[t]{17}{*}{ S2tz } & \multirow[t]{3}{*}{ Interhill basin } & Murarichintala (10) & 1934 & 1.5 \\
\hline & & Kottalu(12) & 372 & 0.3 \\
\hline & & Total & 2306 & 1.8 \\
\hline & \multirow[t]{7}{*}{ Gently sloping midlands } & Balapanur(16) & 6599 & 4.9 \\
\hline & & Simhadripuram (17) & 7583 & 5.7 \\
\hline & & Simhadripuram-Agraharam(18) & 9125 & 6.8 \\
\hline & & Parnapalli(22) & 446 & 0.3 \\
\hline & & Agraharam(23) & 2690 & 2.0 \\
\hline & & Agraharam - Simhadripuram (26) & 369 & 0.3 \\
\hline & & Total & 26812 & 20.0 \\
\hline & \multirow[t]{7}{*}{ Colluvic-alluvial sector } & Agadur(32) & 633 & 0.5 \\
\hline & & Tondur - Agadur(34) & 709 & 0.5 \\
\hline & & Pernapadu(37) & 3689 & 2.8 \\
\hline & & Pernapadu - Tondur(38) & 4358 & 3.3 \\
\hline & & Agadur - Pernapadu(41) & 3613 & 2.7 \\
\hline & & Bhadrampalli(42) & 448 & 0.3 \\
\hline & & Total & 13450 & 10.1 \\
\hline \multirow[t]{4}{*}{ S2zg } & \multirow[t]{4}{*}{ Gently sloping midlands } & Vemula(20) & 1667 & 1.2 \\
\hline & & Velpula(21) & 1326 & 1.0 \\
\hline & & Velpula - Vemula(28) & 712 & 0.5 \\
\hline & & Total & 3705 & 2.7 \\
\hline \multirow[t]{8}{*}{ S2rtz } & \multirow[t]{3}{*}{ Interhill basin } & Tatireddipalli(11) & 788 & 0.6 \\
\hline & & Santakovur(13) & 548 & 0.4 \\
\hline & & Total & 1336 & 1.0 \\
\hline & \multirow[t]{5}{*}{ Gently sloping midlands } & Balapanur - Sunkesula(19) & 4294 & 3.2 \\
\hline & & Sunkesula(24) & 2778 & 2.1 \\
\hline & & Agraharam - Sunkesula (25) & 802 & 0.6 \\
\hline & & Sunkesula - Simhadripuram(27) & 741 & 0.6 \\
\hline & & Total & 8615 & 6.5 \\
\hline
\end{tabular}


Vempalle (6894 ha, $27.39 \%$ of cultivated area) and Vemula (3613ha, 17.29\% of cultivated area) mandals where groundnut is grown in sandy loam to clay loam soils.

\section{Suitability for banana}

The suitability of 43 soil mapping units for banana is evaluated using the criteria of Sys, et al. (1993). The SMU's from 1 to 8 in hills and ridges (54812ha, $42.62 \%$ of total area) are not suitable for banana cultivation but respond well to inputs and conservation measures. The twenty soil mapping units in interhill basin covers 45255 ha (35.19\% of total area). Among 20 SMUs, only 8 SMUs (viz., 12, 18, 21, 23, $24,25,26$ and 28) are moderately suitable but needs careful management of organic carbon. This unit covers 14.13 per cent of area in interhill basin (18174 ha) while 7 SMUs (22688 ha,17.65\% of area ), viz., $11,13,14,17,19,20$ and 27) are marginally suitable with limitation of calcium carbonate, low organic carbon, strong alkalinity, coarse fragments and low available $\mathrm{K}$ and DTPA-Zn. Fifteen soil mapping units (SMU 29 to 43 ) on colluvio-alluvial plains (28542 ha, 22.19\%) have very deep, moderately well drained, calcareous and strongly to moderately alkaline black soils with high shrink-swell potentials. Only five SMUs (32, 38, 40, 41 and 43) are marginally suitable for banana (Table 6). The results from land evaluation for drip irrigation shows that among 13 units are evaluated as marginally suitable for banana are evaluated. Nine SMUs are highly suitable (34502 ha) since eight SMUs (13882ha) are of moderately suitable.

\section{Conclusions and recommendations}

In the present study, Pulivendula tehsil of YSR Kadapa district is selected to identify visual signatures of dry land degradation. The land resource data on 1:25000 scales was used. The field investigations in selected sites were made and analyzed the regional climatic and crop data in support of objectives of the study. The following conclusions were drawn as given under:

- The mean monthly rainfall over 109 years is $679.59 \pm 237.52 \mathrm{~mm}$. The south west monsoon rainfall is and $340.69 \mathrm{~mm}$ with a deficit of $60 \mathrm{~mm}$ to that critical rainfall of $400 \mathrm{~mm}(50.28 \%$ of total rainfall). The mean air temperature is favourable for groundnut with values of $30.7^{\circ} \mathrm{C}$ to $36.9^{\circ} \mathrm{C}$. The region has an aridity index of 11.29 to 14.25 indicating semiarid conditions. It is found that $64 \%$ of cases in June, there is no risk of pluvial erosion, whereas 50\% of cases in September/October (43\%) have favourable for triggering pluvial linear erosion.

- The soils identified and classified under four orders (Alfisols, Entisols, Inceptisols and Vertisols), five suborders (Ustalfs, Orthents, Aquepts, Ustepts and Usterts) seven greatgroups (Paleustalfs, Rhodustalfs, Haplustalfs, Ustorthents, Halaquepts, Haplustepts and Haplusterts), twelve subgroups, eighteen families and twenty five series. Alfisols cover about 6367 ha (4.8 \%), Entisols about 5477 ha (4.1\%), Inceptisols 47342 ha (35.5 \%) and Vertisols 31118 ha (23.3 \%). The soil map of 43 mapping units was made using GIS.

- The soils are grouped into five depth classes and eight textural classes.. The mean clay for A 
Table 6. Suitability of soil mapping units for banana under drip irrigation.

\begin{tabular}{|c|c|c|c|c|c|c|c|}
\hline \multirow[t]{2}{*}{ Land form } & \multirow[t]{2}{*}{ Soil mapping unit } & \multicolumn{2}{|l|}{ Area } & \multicolumn{2}{|c|}{ Banana } & \multicolumn{2}{|l|}{ Drip } \\
\hline & & $\begin{array}{l}\text { ha } \\
\text { (hectar } \\
\text { es) }\end{array}$ & $\begin{array}{l}\text { Per } \\
\text { cent } \\
(\%)\end{array}$ & $\begin{array}{l}\text { Rat- } \\
\text { ing }\end{array}$ & $\begin{array}{l}\text { Suitabil- } \\
\text { ity class }\end{array}$ & $\begin{array}{l}\text { Rat- } \\
\text { ing }\end{array}$ & $\begin{array}{l}\text { Suitabil- } \\
\text { ity class }\end{array}$ \\
\hline \multirow[t]{8}{*}{$\begin{array}{l}\text { Hills and } \\
\text { ridges }\end{array}$} & $\begin{array}{l}\text { 1. Rockoutcrops ( R)- } \\
\text { Kanampalli(Kpl) }\end{array}$ & 7953 & 6.18 & 3.34 & N2 & 17.96 & N2 \\
\hline & $\begin{array}{l}\text { 2. Rockoutcrops }{ }^{\circledR-}- \\
\text { Ganganapalle(Ggp) }\end{array}$ & 7464 & 5.80 & 9.65 & N2 & 21.60 & N2 \\
\hline & $\begin{array}{l}\text { 3. Rockoutcrops }{ }^{\circledR}- \\
\text { Rachanakuntapalle(Rkp) }\end{array}$ & 24939 & 19.39 & 3.72 & N2 & 24.30 & N2 \\
\hline & $\begin{array}{l}\text { 4. Rockoutcrops }{ }^{\circledR--} \\
\text { Lingala(Lgl) }\end{array}$ & 6410 & 4.98 & 4.26 & N2 & 25.52 & N2 \\
\hline & $\begin{array}{l}\text { 5. Rachanakuntapalle } \\
(\mathrm{Rkp}) \text { - rockoutcrops }{ }^{\circledR}\end{array}$ & 1333 & 1.04 & 4.12 & N2 & 53.20 & N2 \\
\hline & $\begin{array}{l}\text { 6. Ganganapalle(Ggp)- } \\
\text { Rockoutcrops }{ }^{\circledR}\end{array}$ & 677 & 0.53 & 16.40 & N2 & 33.25 & N2 \\
\hline & $\begin{array}{l}\text { 7.Rockoutcrops }{ }^{\circledR}- \\
\text { Mupendranpalle(Mpl) }\end{array}$ & 3572 & 2.78 & 15.60 & N2 & 29.93 & N2 \\
\hline & $\begin{array}{l}\text { 8. Mupendranpalle(Mpl) } \\
\text { - Rockoutcrops }{ }^{\circledR}\end{array}$ & 2464 & 1.92 & 11.32 & N2 & 76.95 & S1 \\
\hline \multirow{17}{*}{$\begin{array}{l}\text { Interhill ba- } \\
\text { sin }\end{array}$} & 9. Tallalapalle(Tlp) & 1829 & 1.42 & 14.21 & N2 & 90.25 & S1 \\
\hline & 10. Murarichintla(Mct) & 1934 & 1.50 & 15.83 & N2 & 85.50 & S1 \\
\hline & 11. Tatireddipalle(Trp) & 788 & 0.61 & 49.42 & S3 & 95.00 & S2 \\
\hline & 12. Kottalu(Ktl) & 372 & 0.29 & 69.04 & S2 & 68.40 & S1 \\
\hline & 13. Santhakovur(Skv) & 548 & 0.43 & 41.42 & S3 & 72.20 & S1 \\
\hline & $\begin{array}{l}\text { 14. Murarichintala(Mct)- } \\
\text { Tallapalle(TIP) }\end{array}$ & 508 & 0.39 & 43.73 & S3 & 95.00 & S3 \\
\hline & 15. Cherlapalle(Cpl) & 184 & 0.14 & 19.81 & N1 & 85.50 & S1 \\
\hline & 16. Balapanur(Bpr) & 6559 & 5.10 & 41.18 & S3 & 95.00 & S1 \\
\hline & $\begin{array}{l}\text { 17. Simhadripuram } \\
\text { (Spm) }\end{array}$ & 7583 & 5.90 & 43.73 & S3 & 90.25 & S1 \\
\hline & $\begin{array}{l}\text { 18. Simhadripuram } \\
\text { (Spm)- Agraharam } \\
\text { (Ahm) }\end{array}$ & 9125 & 7.10 & 61.29 & S3 & 67.50 & S1 \\
\hline & $\begin{array}{l}\text { 19. Balapanur(Bpr)- } \\
\text { Sunkesula(Skl) }\end{array}$ & 4294 & 3.34 & 52.89 & S3 & 56.53 & S1 \\
\hline & 20. Vemula(Vml) & 1667 & 1.30 & 40.00 & S3 & 85.50 & S2 \\
\hline & 21. Velpula(Vpl) & 1326 & 1.03 & 68.64 & S2 & 85.74 & S1 \\
\hline & 22. Parnapalle(Prp) & 446 & 0.35 & 30.78 & N1 & 90.25 & S2 \\
\hline & 23. Agraharam(Ahm) & 2690 & 2.09 & 76.71 & S2 & 90.25 & S1 \\
\hline & 24. Sunkesula(Skl) & 2778 & 2.16 & 64.60 & S2 & 90.25 & S2 \\
\hline & $\begin{array}{l}\text { 25. Agraharam(Ahm)- } \\
\text { Sunkesula(Skl) }\end{array}$ & 802 & 0.62 & 71.87 & S2 & 80.75 & S2 \\
\hline
\end{tabular}


Table 6. Continued...

\begin{tabular}{|c|c|c|c|c|c|c|c|}
\hline \multirow[t]{2}{*}{ Land form } & \multirow[t]{2}{*}{ Soil mapping unit } & \multicolumn{2}{|l|}{ Area } & \multicolumn{2}{|c|}{ Banana } & \multicolumn{2}{|l|}{ Drip } \\
\hline & & $\begin{array}{l}\text { ha } \\
\text { (hectar } \\
\text { es) }\end{array}$ & $\begin{array}{l}\text { Per } \\
\text { cent } \\
(\%)\end{array}$ & $\begin{array}{l}\text { Rat- } \\
\text { ing }\end{array}$ & $\begin{array}{l}\text { Suitabil- } \\
\text { ity class }\end{array}$ & $\begin{array}{l}\text { Rat- } \\
\text { ing }\end{array}$ & $\begin{array}{l}\text { Suitabil- } \\
\text { ity class }\end{array}$ \\
\hline \multirow[t]{3}{*}{$\begin{array}{l}\text { Interhill ba- } \\
\text { sin }\end{array}$} & $\begin{array}{l}\text { 26. Agraharam(Ahm)- } \\
\text { Simhadripuram(Spm) }\end{array}$ & 369 & 0.29 & 66.82 & S2 & 17.96 & s1 \\
\hline & $\begin{array}{l}\text { 27. Sunkesula(Skl)- Sim- } \\
\text { hadripuram(Spm) }\end{array}$ & 741 & 0.58 & 58.34 & S3 & 21.60 & S2 \\
\hline & $\begin{array}{l}\text { 28. . Velpula(Vpl)- . } \\
\text { Vemula(Vml) }\end{array}$ & 712 & 0.55 & 61.16 & S2 & 24.30 & S2 \\
\hline \multirow{16}{*}{$\begin{array}{l}\text { Colluvial- } \\
\text { alluvial pedi- } \\
\text { plains }\end{array}$} & $\begin{array}{l}\text { 29. Bhadrampalle(Bpl)- } \\
\text { Agadur(Agd) }\end{array}$ & 788 & 0.61 & 29.84 & N1 & 25.52 & S2 \\
\hline & $\begin{array}{l}\text { 30.Tondut(Tdr)- } \\
\text { Pernapadu(Ppd) }\end{array}$ & 1351 & 1.05 & 31.12 & N1 & 53.20 & S1 \\
\hline & 31.Tondur(Tdr) & 3568 & 2.77 & 29.07 & N1 & 33.25 & S1 \\
\hline & 32. Agadur(Agd) & 633 & 0.49 & 48.45 & S3 & 29.93 & S1 \\
\hline & $\begin{array}{l}\text { 33.Pernapadu(Ppd)- } \\
\text { Gondipalle(Gpl) }\end{array}$ & 853 & 0.66 & 29.17 & N1 & 76.95 & S2 \\
\hline & $\begin{array}{l}\text { 34. Tondur(Tdr)- Aga- } \\
\text { dur(Agd) }\end{array}$ & 709 & 0.55 & 34.88 & N1 & 90.25 & S1 \\
\hline & $\begin{array}{l}\text { 35.Pulivendula(Pvd)- } \\
\text { Pernapadu(Ppd) }\end{array}$ & 101 & 0.08 & 23.27 & N2 & 85.50 & S1 \\
\hline & $\begin{array}{l}\text { 36.Goturu(Gtr)- } \\
\text { Gondipalle(Gpl) }\end{array}$ & 1501 & 1.17 & 33.80 & N1 & 95.00 & S1 \\
\hline & 37. Pernapadu(Ppd) & 3689 & 2.87 & 34.20 & N1 & 68.40 & S1 \\
\hline & $\begin{array}{l}\text { 38. Pernapadu(Ppd)- } \\
\text { Tondur(Tdr) }\end{array}$ & 4358 & 3.39 & 32.15 & N1 & 72.20 & S1 \\
\hline & 39. Gondipalle(Gpl) & 1683 & 1.31 & 22.72 & N1 & 95.00 & S3 \\
\hline & 40. Goturu(Gtr) & 1707 & 1.33 & 41.18 & S3 & 85.50 & S1 \\
\hline & $\begin{array}{l}\text { 41. Agadur(Agd)- Perna- } \\
\text { padu(Ppd) }\end{array}$ & 3613 & 2.81 & 42.75 & S3 & 95.00 & S1 \\
\hline & 42. Bhadrampalle(Bpl)- & 448 & 0.35 & 17.44 & N2 & 90.25 & S1 \\
\hline & 43. Pulivendula(Pvd) & 3540 & 2.75 & 15.99 & N2 & 67.50 & S1 \\
\hline & Total & 128609 & 100 & & & 56.53 & \\
\hline
\end{tabular}

horizons is $39.64 \pm 14.25 \%$ and a range of $12.7 \%$ in P18 to $60.2 \%$ in P21. These soils are slightly to strong alkalinity $(\mathrm{pH} 8.5)$ with mean organic carbon of $7.26 \pm 3.13 \mathrm{gkg}^{-1}$ and mean calcium carbonate of $87.62 \pm 46.57 \mathrm{~g} /$. The high $\mathrm{pH}(>9.0)$ in B horizons have strong positive correlation with $\mathrm{CaCO}_{3}\left(\mathrm{r}=0.52^{* *}\right)$ and exchangeable sodium $\left(\mathrm{r}=0.39^{*}\right.$ table value of $0.37 \mathrm{DF}$ of 45$)$. The mean organic carbon is $13.58 \pm 4.24 \mathrm{gkg}^{-1}$ showing negative correlation with $\mathrm{pH}\left(\mathrm{r}=-0.55^{* *}, \mathrm{p}=\right.$ 0.01 level, table value of 0.48$)$ and positive with exchangeable sodium $\left(r=0.38^{*}, p=0.05\right.$ level, table value of 0.38$)$. The mean CEC is $23.93 \pm 7.64$ coml. $(+) \mathrm{kg}^{-1}$ in soils on quartzite as against the soils on shale with mean CEC of $30.52 \pm 13.12$ coml. $(+) \mathrm{kg}^{-1}$. The data shows that seventy two per cent of 
soils have high (48\%) to very high CEC (24\%) and confine to gently sloping areas. The one way ANOVA analysis shows that there is a significant difference between the horizons for sand, clay, organic carbon and CEC $(\mathrm{p}<0.01)$ where as $\mathrm{pH}, \mathrm{EC}$ and ESP at $\mathrm{p}<0.05$ level.

- The results of erodibility of hill land soils show that the soils with a textural sequence of scl-cl (SMU-1, 3 \&5,) have high (SMU-1) to moderate erodibility (SMU3\&5). The SMU 2, 6, 7 \& 8 have textural class of sandy clay to clay with low to moderate erodibility. The highly erodible soils (SMU -1) cover 7953 ha (6.18\%), moderately erodible soils (SMU 2, 3, 5\& 6) of 34413 ha $(26.76 \%)$ and low erodible soils of 12446 ha $(9.68 \%)$.

- The shallow soils on hills and ridges have 8 units with medium quality SQI. The 22 units in inter hill basin are rated as medium to high quality. The 'good growth plan for groundnut demands drought tolerant varieties suitable for three dominant landscape positions such as hills and ridges (54812ha, $42.62 \%$ of total area), interhill basins (45255ha, 35.19\% of total area) and colluvio alluvial landforms (28542ha, $22.19 \%$ of total area. The red-black soils in the region have low available nitrogen, $47 \%$ under low available phosphorus and $74 \%$ as high status of available potassium but, deficit in iron and zinc. The deep black soils with sodic enriched clay are well distributed in north central parts of Pulivendula (23533 ha, $18.29 \%$ of total area). These soils are weakly to moderately susceptible to water erosion but have high erosion risk and high erodibility covering 16364 ha (13.03\% of total area) in hilly region of Pulivendula.

- The results from suitability analysis of banana under drip irrigation show that 56091 ha of land in interhill basins and colluvio-alluvial deposits are evaluated as suitable (S2 and S3) for banana as against the current area of 22000ha. Further the study shows that 34502 ha of land is evaluated as highly suitable for drip irrigation system. We suggested land conservation directives such as construction of bench terraces with rocks and planted with vetiver grass on the edges of the terrace.

- The results from the study led to the conclude that combining crop residue with organic amendment and runoff hedges is the best treatment for steep slope areas, although it is crucial to manage the pigeon-pea (runoff) hedges to achieve higher groundnut yield. The agropedological approach facilitates to capture a greater range of climatic conditions and evaluate the biophysical and socio-economic benefits of the most promising SLM techniques such as residue mulch combined with pigeon pea hedges against the traditional baseline practice of groundnut - pigeon pea intercropping. It is strongly advocated in semi-arid regions to have long-term historic rainfall statistics to provide a unique rainfall scenarios to express the agricultural and soil erosion risk associated with climate variability.

\section{Acknowledgement}

Author wish to express thanks to technical staff for their help during field survey and also to the scientific staff of regional centre, ICAR-NBSS\&LUP, Hebbal for their useful discussions and regular 
interaction on agro ecosystem health. Thanks to Mr. Madeletti and Smt. Sujatha for GIS work and word processing. This manuscript is prepared from the institute research council (IRC) approved project entitled "visual signs of degradation of drylands in Pulivendula tehsil, Kadapa district, Andhra Pradesh".

\section{Abbreviations}

$\mathrm{AP}=$ Andhra Pradesh, $\mathrm{CV}=$ coefficient of variation, $\mathrm{CVR}$ RFT = climatic vulnerability index for rainfed tropics, FAO=Food and Agriculture Organization, GIS =Geographical information system, ha = hectare, Idm =De Martonne aridity index (IDM), IRS = Indian Remote Sensing Satellite, LGP = length of growing period, LISS = linear imaging self scanning sensor, NDVID= normalized difference in vegetation index, SD=standard deviation, SMU=soil mapping unit, SPI =standardized precipitation index, $\mathrm{SQI}=$ soil quality rating, $\mathrm{t}=$ tonne, USDA=United States Department of Agriculture, USLE: Universal Soil Loss Equation, $\mathrm{VCI}=$ vegetation condition index, $\mathrm{Yr}=$ year.

\section{References}

Adriaenssens, V., De Baets, B., Goethals, P.L.M. and Pauw, N.D. (2004). Fuzzy rule-based models for decision support in ecosystem management. Science of The Total Environment, 319(1-3): 1-12.

Allan, E., Manning, P., Alt, F., Binkenstein, J.; Blaser, S., Blüthgen, N. and Kleinebecker, T. (2015). Land use intensification alters ecosystem multifunctionality via loss of biodiversity and changes to functional composition. Ecology Letters, 18: 834-843.

Altieri, M.A, Nicholls, C.I., Henao, A. and Lana, M.A. (2015). Agroecology and the design of climate change resilient farming systems. Agronomy for Sustainable Development, 35: 869-890.

Amiri, V., Rezaei, M. and Sohrabi, N. (2014). Groundwater quality assessment using entropy weighted water quality index (EWQI) in Lenjanat. Iran. Environmental Earth Science, 72(9): 3479-3490.

Arowolo, A.O., Deng, X., Olatunji, O.A. and Obayelu, A.E. (2018). Assessing changes in the value of ecosystem services in response to land-use/land-cover dynamics in Nigeria. Science of the Total Environment, 636: 597-609.

Andow, D.A. and Hidaka, K. (1989). Experimental natural history of sustainable agriculture: syndromes of production. Agriculture Ecosystems and Environment, 27: 447-462.

Basu, H., Mahendra Kumar, K., Paneerselvam, S. and Chaki, A. (2009). Study of Provenance Characteristics and Depositional History on the Basis of $\mathrm{U}$, Th and $\mathrm{K}$ Abundances in the Gulcheru Formation, Cuddapah Basin in TummalapalleSomalollapalle Areas, Cuddapah-Anantapur Districts, Andhra Pradesh. Journal of the Geological Society of India, 74: 318328.

Beroya-Eitner, M.A. (2016). Ecological vulnerability indicators. Ecoligucal Indicators, 60: 329-334.

Bhaskar, B.P., Sunil Maske, Ramesh Kumar, S.C. et al. (2019). Appraisal of Land Resources to Assess Climate Change Impacts for Rainfed Groundnut (Arachis Hypogaea L) Production Potential in Pulivendula Tehsil, YSR Kadapa District, Andhra Pradesh, India. Indian Journal of Plant and Soil, 6(1): 5-19.

Bhaskar, B.P., Bobade, S.V., Gaikwad, S.S., Dipak Sarkar, Anantwar, S.G. and Tapas, B. (2015). Soil informatics for agricultural land suitability assessment in Seoni district, Madhya Pradesh, India. Indian Journal of Agricultural Research, 49: 315-320

Bhavani P. Chakravarthi V., Roy , P.S., Joshi, P.K. and Chandrasekar, K. (2017). Long-term agricultural performance and climate variability fordrought assessment: a regional study from Telangana and Andhra Pradesh states, India. Geomatics, Natural hazards and Risks, 8(2): 822-840. 
Chaliha, S., Sengupta, A., Sharma, N. and Ravindranath, N.H. (2012).Climate variability and farmer's vulnerability in a floodprone district of Assam. International Journal of Climate Change Strategies and Management, 4: 179-200.

Chuvieco E., Martínez S., Roman M.V., Hantson S., Pettinari M.L. (2014). Integration of ecological and socio-economic factors to assess global vulnerability to wildfire. Global Ecology and Biogeography, 23(2): 245-258.

Conway. G.R. (1985). Agro-ecosystem analysis. Agriculture Administration, 20: 31-55. https://doi.org/10. 1016/0309-586X(85) 90064-0

Cox, F.R. (1979). Effect of temperature treatment on peanut vegetative and fruit growth. Peanut Science, 6: 14-17.

Dent, D. and Young, A. (1981). Soil Survey and Land Evaluation; George Allen \& Unwin: London, UK.

Dewis, J. and Freitas, F. (1970). Physical and Chemical Methods of Soil and Water Analysis. FAO Soils Bulletin. 10: 275.

Directorate of Economics and Statistics (2017). Pocket book of Agricultural Statistics. Ministry of Agriculture and Family welfare. New Delhi. pp.1-155.

Dominati, E., Patterson, M. and MacKay, A. (2010). A framework for classifying and quantifying the natural capital and ecosystem services of soils. Ecological Economics, 69: 1858-1868

Dutta, D, Kundu, A., Patel, N.R., Saha, S.K. and Siddiqui, A.R. (2015). Assessment of agricultural drought in Rajasthan (India) using remote sensing derived vegetation condition index (VCI) and standardized precipitation index (SPI). The Egyptian Journal of Remote Sensing and Space Sciences, 18: 53-63.

FAO. (1976). A framework for land evaluation. FAO. Soils Bulletin No. 32, Rome.

FAO. (2007). Land evaluation: towards a revised framework. Land and Water Discussion Paper No 6. Rome: Food and Agriculture Organization of the United Nations.

FAO. (2018). Ethiopia: Report on feed inventory and feed balance. FAO, Food and Agriculture Organization of the United Nations, Rome, Italy.

Farley, J. and Voinov, A. (2016). Economics, socio-ecological resilience and ecosystem services. Journal of Environmental Management, 183(2): 389-398.

Foley, J.A., Defries, R., Asner, G.P., Barford, C., Bonan, G., Carpenter, S.R., Chapin, F.S., Coe, M.T., Daily, G.C. and Gibbs, H.K. (2005). Global consequences of land use. Science, 309: 570-574.

Gong, J., Li, J.,Yang, J., Li, S. and Tang, W. (2017). Land Use and Land Cover Change in the Qinghai Lake Region ofthe Tibetan Plateau and Its Impact on Ecosystem Services. International Journal of Environmental Research and Public Health, 14: 818.

Gopinath, M. and Bhat, A.R.S. (2012). Impact of climate change on rainfed agriculture in India: A case study of Dharwad. International Journal of Environmental Science and Technology, 3: 368.

Government of India. (2008). National Action Plan on Climate Change; Government of India, New Delhi, India, pp. 56.

Grunwald, S. (2005). Environmental Soil-Landscape Modeling. Geographic Information Technologies and Pedometrics, 1st ed.; CRC Press: Boca Raton, FL, USA, pp. 37.

Hair, J.F., Hult, G.T.M., Ringle, C.M. and Sarstedt, M. (2017). A Primer on Partial Least Squares Structural Equation Modelling (PLS-SEM). 2nd Ed. Thousand Oaks, CA: Sage

Hazelton, P. and Murphy, B. (2007). Interpreting soil test results. What do all numbers mean. 2nd edition. University of Technology, Sydney, CSIRO publishing. Australia.

Hazelton, P.A. and Murphy, B.W. (2016). Third Edition. What Do All the Numbers Mean? A Guide to the Interpretation of Soil Test Results. Melbourne: CSIRO Publishing.

Heltberg, R., Siegel, P.B. and Jorgensen, S,L. (2009). Addressing human vulnerability to climate change: toward a 'no-regrets' approach. Global Environmental Change, 19(1): 89-99.

Hou, K., Li, X. and Zhang, J. (2015). GIS analysis of changes in ecological vulnerability using a SPCA model in the loess plateau of Northern Shaanxi, China. International Journal of Environmental Research and Public Health , 12(4): 4292-4305.

Idowu, O.J., Van ES, H.M., Abawi, G.S., Wolfe, D.W., Schindelbeck, R.R., Moebius clune, B.N. and Gugino, B.K. (2009). Use of an integrative soil health test for evaluation of soil management impacts. Renewable Agriculture and Food Systems, 24: 214-224.

Jonathan, G., Chapman, G. and Murphy, B. (2015). Land management within capability: a new scheme to guide sustainable land management within NSW, Australian Soil Research, 10: 1071/SR14196. 
Jongman, R.H.G. (2004). The new dimension of the European landscape, Springer (Wageningen UR Frontis series vol. 4) Dordrecht

Kang, H., Tao, W.D., Chang, Y., Zhang, Y., Li, XX. and Chen, P. (2018). A feasible method for the division of ecological vulnerability and its driving forces in Southern Shaanxi. Journal of Cleaner Production, 205: 619-628.

Kong, L., Zheng, H., Xiao, Y., Ouyang, Z., Li, C., Zhang, Jand Huang, B.(2018). Mapping Service Bundles to Detect Distinct Types of Multifunctionality within the Diverse Landscape of the Yangtze River Basin, China. Sustainability,10: 857.

Krishnamurthy, P.K., Lewis, K. and Choularton, R.J. (2012). Climate Impacts on Food Security and Nutrition-A Review of Existing Knowledge; and WFP's Office for Climate Change, Environment and Disaster Risk Reduction. Exeter, UK.

Lal, R. (2016). Soil health and carbon management. Food and Energy Security, 5(4): 212-222.

Li, A.N., Wang, A.S., Liang, S.L. and Zhou, W.C. (2006). Eco-environmental in mountainous region using remote sensing and GIS: A case study in the upper reaches of Minjiang River. Ecological Modelling , 192(1-2): 175-187.

Mandal, C., Mandal, D.K., Srinivas, C.V., Sehgal, J. and Velayutham, M. (1999). Soil Climatic Database for Crop Planning in India. Technical Bulletin Number 53, NBSS and LUP, pp. 1014.

Millennium Ecosystem Assessment (MEA). (2005). Ecosystems and human well-being: synthesis. Washington D.C., Island Press, pp. 155.

Mongi, H., Majule, A.E. and Lyimo, J.G. (2010).Vulnerability and adaptation of rain fed agriculture to climate change and variability in semi-arid Tanzania. African Journal of Environmental Science and Technology, 4(6): 371-381.

Mouchet, M.A., Paracchini, M.L., Schulp, C.J.E., Stürck, J., Verkerk, P.J., Verburg, P.H. and Lavorel, S. (2017). Bundlesof ecosystem (dis)services and multifunctionality across European landscapes. Ecological Indicators, 73: 23-28.

Murthy, C.S., Chakraborty. A., Seshai Sai, M.V.R. and Roy, P.S. (2011). Spatio-temporal analysis of the droughts of kharif 2009 and 2002. Current Science, 100: 1786-1788.

Naidu, L.G.K., Niranjana, K.V., Ramamurthy, V., Ramesh kumar, S.C., Anil kumar, K.S. and Thayalan, S. (2009). Planning optimum land use based on biophysical and economic resources in Pulivendula agricultural division, Kadapa district, Andhra Pradesh. NBSS\&LUP. Publication. No. 1029. NBSS\&LUP, Nagpur, pp. 184.

Nataraja, S. and Ram Mohan, H.S. (2010). Trend detection in rainfall and precipitation index as adrought assessment index for rice-wheat productivity over IGR in India. International Journal of Climatology, 31: 1694-1709..

Orr, B.J., A.L. Cowie, V.M. Castillo Sanchez, P. Chasek, N.D. Crossman, A. Erlewein, G. Louwagie, M. Maron, G.I. Metternicht, S. Minelli, A.E. Tengberg, S. Walter, and S. Welton. (2017). Scientific Conceptual Framework for Land Degradation Neutrality. A Report of the Science-Policy Interface. United Nations Convention to Combat Desertification (UNCCD), Bonn, Germany. ISBN 978-92-95110-42-7 (hard copy), 978-92-95110-41-0 (electronic copy).

OEH (Office of Environment and Heritage) (2012). The Land and Soil Capability Assessment Scheme: Second Approximation. A General Rural Land Evaluation System for New South Wales. Sydney.

Parmar, R.S. (2013). Influence of rainfall distribution on the productivity of groundnut in Bhavnagar district of Gujarat state. International Journal of Agricultural Sciences and Veterinary Medicine, 1(1): 1-7.

Peng, W., Robinson, B.E., Hua Zheng, H., Li, C., Wang, F. and Ruonan Li , R. (2019). Telecoupled Sustainable Livelihoods in an Era of Rural-Urban Dynamics: The Case of China. Sustainability, 11:2716; https://doi.org/10. 3390/su1 1092716

Piya, L., Maharjan, K.L. and Joshi, N.P. (2012).Vulnerability of rural households to climate change and extremes: Analysis of Chepang households in the Mid-Hills of Nepal. In Proceedings of the International Association of Agricultural Economics (IAAE)Triennial Conference, Foz do Iguacu, Brazil, 18-24 August 2012; IAAE: Foz do Iguacu, Brazil, pp. 18-24.

Planning Commission. (2012). Final Report of Minor Irrigation and Watershed Management for the Twelfth Five Year Plan (2012-2017); Government of India: New Delhi, India, pp. 3-4.

Polsky, C., Neff, R. and Yarnal, B. (2007). Building comparable global change vulnerability assessments: the vulnerability scoping diagram. Global Environ Change, 17(3-4): 472-485.

Radha Kumari, C., Sudheer, K.V.S., Niveditha, M. and Sahadeva Reddy, B. (2016). Performance of Kharif crops as influenced by time of sowing in rainfed alfisols. International Journal of Agricultural Sciences,12(1): 106-114.

Rajendra Hegde, Bhaskar, B.P. , Niranjana, K.V., Ramesh Kumar, S.C., Ramamurthy, V., Srinivas, S. and Singh, S.K. (2018). Land evaluation for groundnut (Arachis hypogaea L.) production in Pulivendula tehsil, Kadapa district, Andhra Pradesh, 
India. Legume Research Online, 1-8.

Ritung, S., Wahyunto, A. F. and Hidayat, H. (2007). Land Suitability Evaluation with a case map of Aceh Barat District. Indonesian Soil Research Institute and World Agroforestry Centre, Bogor, Indonesia

Saidi, N. and Spray, C. (2018). Ecosystem services bundles: Challenges and opportunities for implementation and further research. Environmental Research Letters, 13: 113001.

Sengeda, A.Z., Kahinda, F.C., Kashaga, R.A.L., Semu, E., Mahonga, C.P. and Mkanda, F.X. (2014). Testing of Decision Making Tools for Village Land Use Planning and Natural Resources Management in the Kilimanjaro Region. Open Journal of Soil Science, 4: 446-458

Schoeneberger, P.J., D.A. Wysocki, E.C. Benham, and Soil Survey Staff. (2012). Field book for describing and sampling soils,Version 3.0. Natural Resources Conservation Service, National Soil Survey Center, Lincoln, NE.

Shalaby, A., AbdelRahman, M.A.E. and Belal, A.A. (2017).A GIS Based Model for Land Evaluation Mapping: A Case Study North Delta Egypt. Egyptian Journal of Soil Science, 57: 341-342.

Shukla, R., Chakraborty, A. and Joshi, P.K. (2017). Vulnerability of agro-ecological zones in India under the earth system climate model scenarios. Mitigation, Adaptation, Strategic Global Change, 22: 399-425.

Soil Survey Division Staff. (2017). Soil Survey Manual. USDA. Agri Handbook No. 8. pp. 1-587.

Soil Survey Staff. (2014). Keys to Soil Taxonomy, 12th ed., USDA-Natural Resources Conservation Service, Washington, DC.

Sys, C., Van Ranst, E., Debaveye I.J. and Beernaert, F. (1993) Land evaluation. Part III: crop requirements. General Administration for Development Cooperation, Agricultural Publication-No. 7, Brussels, Belgium, pp. 199.

Sun, X., Crittenden, J.C., Li, F., Lu, Z. and Dou, X. (2018). Urban expansion simulation and the spatio-temporal changesof ecosystem services, a case study in Atlanta Metropolitan area, USA. Science of the Total Environment, 622: 974-987.

Topuz ,E. and van Gestel, C.A.M. (2016). An approach for environmental risk assessment of engineered nanomaterials using Analytical Hierarchy Process (AHP) and fuzzy inference rules. Environment International, 92-93: 334-347.

Uddin, K., Murthy, M.S.R., Wahid, S.M. and Matin, M.A. (2016). Estimation of Soil Erosion Dynamics in theKoshi Basin Using GIS and Remote Sensing to assess Priority Areas for Conservation. PLoS One, 11(3): e0150494. https://doi.org/10.1371/ journal.pone.015049

Varaprasad, P.V., Craufurd, P.Q., Summerfield, R.J. and Wheeler T.R. (2000). Effects of short episodes of heat stresson flower production and fruit set of Groundnut (Arachis hypogaea L.). Journal of Experimental Botany, 51(345): 777-784.

Vopravil, J., Janeck, M. and Tippl, M.(2007). Revised Soil Erodibility K-factor for Soils in the Czech Republic. Soil \& Water Research, 2(1): 1-9.

Wischmeier, W.H. and D.D. Smith, D.D. (1978). Predicting rainfall erosion losses: A guide to conservation planning. Washington, D.C: Science and Education Administration. pp. 58.

Wu, X., Wang, S., Fu, B., Liu, Y. and Zhu, Y. (2018). Land use optimization based on ecosystem service assessment: A case study in the Yanhe watershed. Land Use Policy, 72: 303-312.

Zambakas, J. (1992). General Climatology. Department of Geology, National \& Kapodistrian University of Athens: Athens, Greece.

Zhang, X.Q., Wang, L.K., Fu, X.S., Li, H. and Xu, C.D. (2017). Ecological vulnerability assessment based on PSSR in Yellow River Delta. Journal of Cleaner Production, 167: 1106-1111.

Zhou, D., Tian, Y. and Jiang, G. (2018). Spatio-temporal investigation of the interactive relationship between urbanization and ecosystem services: Case study of the Jinginji urban agglomeration, China. Ecological indicators, 95: 152-164.

$* * * * *$

Cite this chapter as: Bhaskar, B.P. (2021). Geo-environmental assessment of semiarid region of Pulivendula tehsil, Kadapa district, Andhra Pradesh, India. In: Biological Diversity: Current Status and Conservation Policies, Volume 1, Eds. Kumar., V., Kumar, S., Kamboj, N., Payum, T., Kumar, P. and Kumari, S. pp. 341-367, https://doi.org/10.26832/aesa2021-bdcp-023 